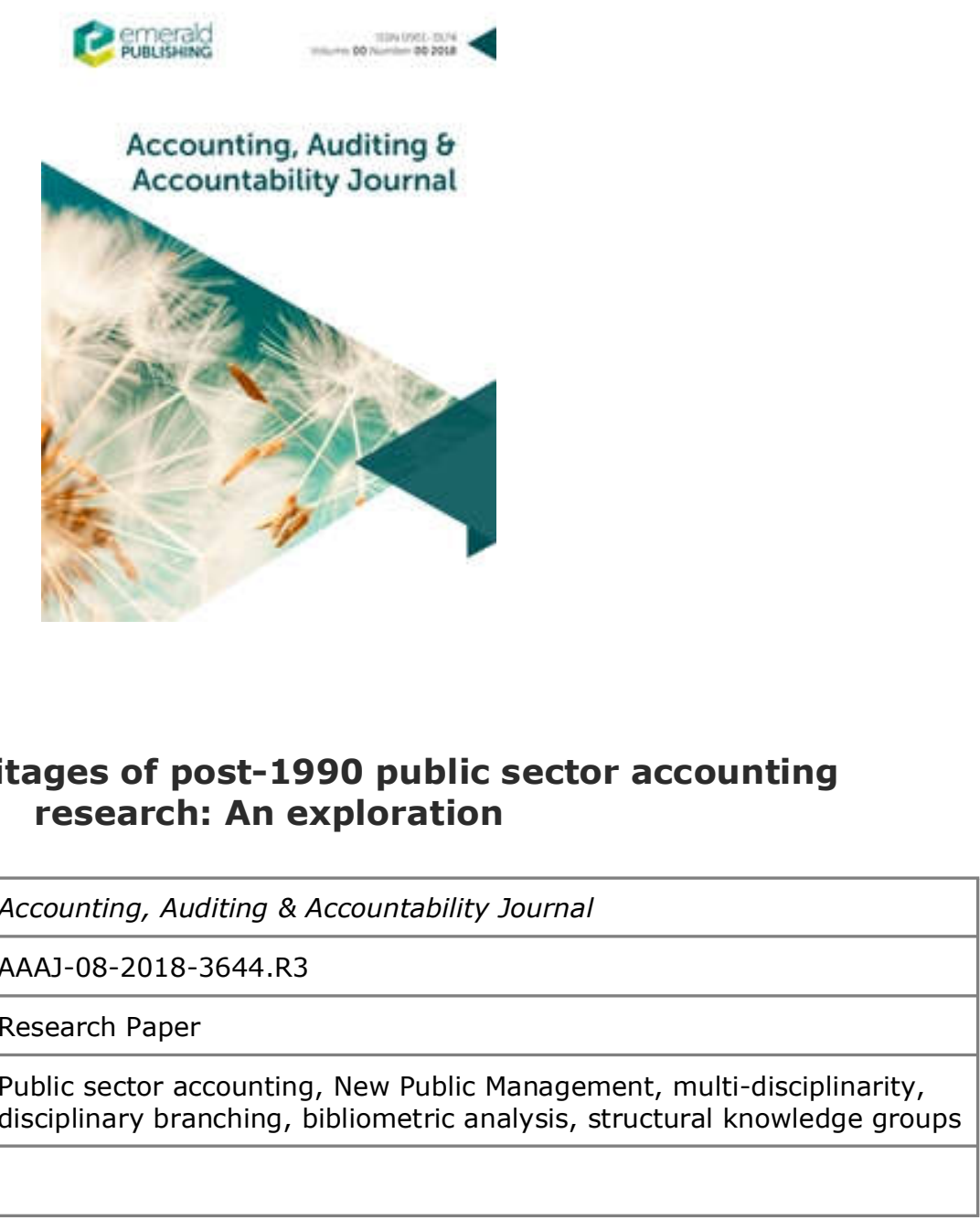

\title{
Intellectual heritages of post-1990 public sector accounting research: An exploration
}

\begin{tabular}{|r|l|}
\hline Journal: & Accounting, Auditing \& Accountability Journal \\
\hline Manuscript ID & AAAJ-08-2018-3644.R3 \\
\hline Manuscript Type: & Research Paper \\
\hline Keywords: & $\begin{array}{l}\text { Public sector accounting, New Public Management, multi-disciplinarity, } \\
\text { disciplinary branching, bibliometric analysis, structural knowledge groups }\end{array}$ \\
\hline \multicolumn{2}{|l}{} \\
\hline
\end{tabular}

\section{SCHOLARONE" \\ Manuscripts}




\title{
Intellectual heritages of post-1990 public sector accounting research: An exploration
}

\author{
Abstract \\ Purpose - The article's aim is to refine prospects for theorising in public sector accounting (PSA) \\ research in order to capture the methodological benefits promised by its multi-disciplinarity. \\ Design/methodology/approach - The study primarily employs a bibliometric analysis of research \\ outputs invoking New Public Management (NPM). Applying a content analysis to Hood (1991), as the \\ most cited NPM source, bibliographic methods and citation/co-citation analysis for the period 1991 \\ to 2018 are mobilised to identify the disciplinary evolution of the NPM knowledge base from a \\ structural and longitudinal perspective.
}

Findings - The analysis exhibits disciplinary branching of NPM over time and its imprints on post1990 PSA research. Given the discourse about origins of NPM-based accounting research, there are research domains behind the obvious that indicate disciplinary fragmentations. For instance, novelty of PSA research is found in Public Value Accounting, continuity is evidenced by transcending contextual antecedents. Interestingly, these domains are loosely coupled. Exploring the role of disciplinary imprints designates prospects for post-NPM PSA research that acknowledges multidisciplinarity and branching in order to deploy insularity as a building block for its inquiries.

Research limitations/implications - Criteria for assessing the limitations and credibility of an explorative inquiry are used, especially on how the proposal to develop cumulative knowledge from post-1990 PSA research can be further developed.

Practical implication - A matrix suggesting a method of ordering disciplinary references enables positioning of research inquiries within PSA research.

Originality/value - By extending common taxonomies of PSA intellectual heritages, the study proposes the 'inquiry-heritage' matrix as a typology that displays patterns of theorisation for positioning an inquiry within PSA disciplinary groundings.

Keywords Public sector accounting, New Public Management, multi-disciplinarity, disciplinary branching, bibliometric analysis, structural knowledge groups

Paper type Research paper 


\section{Introduction}

Public sector accounting (PSA) research since the 1990's has been characterised by scant application of theory and significant reliance on New Public Management (NPM) (Broadbent and Guthrie, 2008; Anessi-Pessina et al., 2016; Steccolini, 2019). Recently, the public administration (PA) and PSA literatures have debated NPM's continued relevance but consensus eludes (Steccolini, 2019; Pollitt, 2016; Hyndman and Lapsley, 2016). There is rising interest in emancipating PSA as a discipline (Steccolini, 2019; Jacobs, 2016) and to better understand the supposed failure of theorising from NPM. This paper reflects on the subject of PSA scholarship as the NPM template emerged as its intellectual heritage. We begin with the often forgotten understanding that PSA stands at the conjunction of PA and accounting literatures.

The PA literature has produced alternative post-NPM framings (Pollitt, 2016; Reiter and Klenk, 2019) and PSA scholars are searching for heuristics to frame post-NPM PSA (Steccolini, 2019; Jacobs, 2016) beyond NPM's doctrinal content (Hood, 1991, 1995a). Such developments include PA's New Public (Value) Governance (Osborne, 2006) and PSA's recognition of Public Service and/or Public Value Accounting (Broadbent and Guthrie, 2008; Moore, 2014), thereby creating the risk of re-establishing 'monopolized scholarly attention' (Steccolini, 2019). However, studies tracking the scope and depth of NPM's conceptual evolution over time are still rare (for recent exceptions, see Chandra and Walker, 2018; Curry and van de Walle, 2018), but nevertheless necessary to expose NPM and, more importantly, to understand the interface with its subject domains, like PSA. We view this effort to be a vital prerequisite to evaluate post-1990 PSA[1] and its interdisciplinarity for framing the heuristics of post-NPM related PSA research.

Claiming NPM's doctrinal content as a distinct school of thought, or even a paradigm[2], within the administrative sciences and as a disciplinary reference for theorising of post-1990 PSA is contested terrain. This is due to the multifaceted epistemic tradition of PA and, correspondingly, to the array of perspectives used within this oeuvre (Riccucci, 2010; Curry and van de Walle, 2018). In a similar vein, theorising in post-1990 PSA research is threatened not only by the, perhaps overstated, 'death' of the NPM paradigm (e.g. Dunleavy et al., 2006). Debate regarding NPM's multi-disciplinarity questions the suitability of theoretical pluralism for delivering research that is creative in its space and rigorous in its methods (e.g. Jeacle and Carter, 2014; Jacobs, 2012). On this, Lukka and Vinnari (2014) made an essential argument about the relative nature of employing theoretical lenses in interdisciplinary accounting research, by distinguishing the interface of method and domain theory. In theorising a substantive subject domain like PSA, mobilising rival theoretical lenses immediately creates ambiguity at their interface to the domain-specific knowledge base. This is, not least, because of the necessity to properly account for the domain-specific or context effect (Lukka and Vinnari, 2014; Whetten, 2009), which is to theorise about what Steccolini (2019) named the 'public' side of accounting scholarship or what Jacobs (2013; Jacobs, 2016) emphasised as the ontological construction of the subject when studying the indigeneity of PSA. 
Arising from this reasoning it is essential to learn more about the creative space for post-NPM related PSA research. For this we need to understand the development of its intellectual provenance, that is, stepping back to the evolution of the NPM doctrine and its intersection with post-1990 PSA research. Exploring NPM as an intellectual source of post-1990 PSA research complements the reasoning about the 'golden cage'-effect (Steccolini, 2019). In this respect, the key question of our research is to identify more deeply the development of NPM-based theorising and how the scope and depth of the NPM knowledge base constitutes an intellectual structure grounding post-1990 PSA research.

Important outputs of NPM research are its intellectual products and the justification of an NPM distinct school of thought (McKinley et al., 1999). Our analysis contrasts the NPM template as associated with Hood (1991) with the dynamics of its (sub)disciplinary evolution on three fronts: subject domains; the array of research approaches; and informing theories. Our research aims to uncover patterns of NPM-based research inquiries, and if they compose an intellectual structure and, perhaps, a cumulative knowledge base for enhancing domain-specific theorising. We use the concept of structural knowledge groups (Pilkington and Meredith, 2009; Córdoba et al., 2012) as the analytical unit for exploring NPM's domains of research pointing to a complementary or dissimilarity of ideas, concepts and the scope of themes associated with NPM's novelty.

We extend the bibliographic methods commonly applied (e.g. Reiter and Klenk, 2019; Broadbent and Guthrie, 2008) with bibliometric methods, in terms of how NPM's inaugural template has been cited and co-cited by others. Combining insights from qualitative, bibliographic-based reviews and the quantitative, bibliometric approach enriches our inquiry (Zupic and Čater, 2015; Chandra and Walker, 2018; Alcaide-Muñoz et al., 2017). We focus on novelty and continuity within NPM's disciplinary groundings, covering the time span from 1991 to 2018. Novelty reasonably goes with a bibliographicbased mapping of NPM's uniqueness relative to concurrent PA ideas and perspectives (Curry and van de Walle, 2018; Zupic and Čater, 2015). Further, our bibliometric methods add insightful descriptions of NPM's continuity as a distinct research domain. Bibliometrics reveal a structural and longitudinal perspective on NPM's knowledge base (Pilkington, 2018; Zupic and Čater, 2015; Alcaide-Muñoz et al., 2017). We use citation analysis to investigate the spread of the NPM idea since Hood's (1991) seminal paper. We also use co-citation analysis to uncover NPM's intellectual structure over time (e.g. Chandra and Walker, 2018). By extending previous bibliometric NPM studies, we discern phases of NPM's disciplinary evolution from when NPM appeared as a new research programme (19912007) to the 2008-2018 emergence of a mature literature based on NPM's domain-specific reasoning. The periodisation is especially useful to further assess post-NPM calls for more interdisciplinary PSA research. Finally, we are attentive for thick descriptions as our means of drawing inferences, especially to address Parker and Northcott's (2016) request for substantiating reasonable ways to extrapolate from evidence and insights.

The paper is structured as follows. First, we consider the outcome state of prior reviews addressing NPM and post-1990 PSA research in order to identify associated debates about prospects and pitfalls 
of interdisciplinary post-1990 research. This accentuates how our research questions derive from the NPM-PSA discourse. Next follows an exposition of our methods before identifying the research outcomes applying bibliometric methods. Finally, we discuss the results with a view to emerging post-NPM templates as intellectual heritage for re-framing PSA research, and conclude by drawing implications for further research.

\section{The intersection between Public Administration, New Public Management and Public Sector Accounting research: Problematisation of the role of intellectual heritages}

Since Hood (1991), NPM as a subject matter has been contested terrain (e.g. Pollitt, 2016; Reiter and Klenk, 2019). The literature concerned with evaluating NPM as a disciplinary field is wide-ranging, revealing the image of NPM-related PSA research as copious but equivocal. Insights have been derived from: critical essays (e.g. Lapsley, 1999, 2008); comparative, primarily country-based evaluation approaches (e.g. Olson et al., 1998; Christensen and Lægreid, 2001, 2007); bibliographicbased, systematic reviews introducing classification schemes (e.g. Broadbent and Guthrie, 2008; Anessi-Pessina et al., 2016); and, most recently, from bibliometric studies tracking NPM's scope and depth of investigation (Curry and van de Walle, 2018; Chandra and Walker, 2018).

Fragmented arrays of evaluation characterise the studies noted above. At the intersection of NPM with PSA the literature ranges from identifying recurrent research topics within each disciplinary field (PA/NPM - Reiter and Klenk, 2019; PSA - Broadbent and Guthrie, 2008; PBB: Mauro et al., 2016) to scrutinising theoretical foundations (referring PSA: Goddard, 2010; Jacobs, 2012, 2016). The reviews further inspect disciplinary origins (institutional research, actor-network theory/ANT; e.g. Modell, 2015a; Justesen and Mouritsen, 2011; Modell et al., 2017b), the suitability of methodological underpinnings (e.g. Parker, 2014) and issues of practical relevance (e.g. van Helden and Northcott, 2010). Theory developments have also been studied while moving from an initial to a more mature state of research. Here, the strength of PSA's interdisciplinarity is threatened by incoherence when paradigmatic insularity is continuously reinforced (Broadbent and Guthrie, 2008; Goddard, 2010; Steccolini, 2019). Focusing on this discourse (e.g. Jacobs and Cuganesan, 2014; Goddard, 2010; van Helden, 2005) demonstrates problematisation of the disciplinary context of PSA research. Disciplinary incoherence of NPM-related research, if accepted, imperils understanding of NPM, PSA and the prospects of PSA beyond NPM.

Considering the body of NPM-related PSA research reviews, the emergence of NPM as a disciplinary field, involving post-1990 PSA research, has been a dynamic process. It covers several facets of schooling (e.g. novelty, continuity, and scope; McKinley et al., 1999) on NPM's way to become a coherent frame for post-1990 PSA theorising. Consequently, exploring NPM's knowledge base across its stages of development may reveal how the intellectual structure emerges. Origins of post-1990 PSA are indicated by structural groupings of frequent research topics, their relationships and their paths of change (Pilkington and Meredith, 2009; Shafique, 2013). For considering the origins and developments of NPM's doctrinal influence over PSA, in the following sections our research design triangulates three modes of inquiry: 
- As a disciplinary research field, what was NPM's initial core and how can we understand the role of PSA research within its doctrinal content (Section 3.1)?

- How did intellectual products commonly associated with NPM emerge, in particular with reference to the disputed novelty of the NPM research programme? Evidence of its intellectual heritages may appear from systematic, bibliographic-based reviews (Section 3.2).

- The discourse on disciplinary incoherence is particularly sensitising. Whilst there are dominant forms of theorising within the NPM-based research realm, the question remains as to why they count for distinct modes of interdisciplinarity at the intersection of NPM and post-1990 PSA? Addressing that question draws towards gaining a global view from bibliometrics as a method to map such disciplinary developments (Section 3.3).

The logic of this inquiry is inductive and reflexive. We aim to know more about what NPM-based PSA research (as introduced in section 3.1) is actually doing. We assume that initial concepts like school of thought (McKinley et al., 1999), disciplinary fragmentation (Abbott, 2001; Córdoba et al., 2012) and structural knowledge groups as the particular unit of bibliometric analysis (Pilkington and Meredith, 2009; Shafique, 2013) are instructive for building the roadmap for our investigation (Eisenhardt, 1989; Parker, 2014). Combining insights from bibliographic (as done in section 3.2) and bibliometric methods (as done in section 3.3) explores how the micro-level identifies intellectual products which show some paradigmatic imprints on the macro-level, signifying either novelty or continuity. The intellectual structure of field-level interdisciplinarity at the intersection of NPM and post-1990 PSA research may thus be exposed. We expect to learn more about the big picture of the theoretic reasoning and, thereby, about prospects to strengthen PSA research from its interdisciplinarity (Steccolini, 2019; Jacobs, 2016).

\section{Issues at stake in New Public Management and Public Sector Accounting interdisciplinarity}

\subsection{Uncovering a disciplinary matrix: NPM as a research programme}

When considering its specificity as a PA research domain (Riccucci, 2010; Wright, 2011), NPM treats politics and administration as separate subjects of interest. It uses the distinction as a template to study an international reform movement. NPM is about administrative practices, their renewal and impact, and can be described in terms of a disciplinary matrix. By a disciplinary matrix we simply mean an enduring pattern of assumptions, concepts, and values constituting a way of viewing what happens in practice (Malmi, 2010; Lukka, 2010).

Hood's (1991) essay on NPM's intellectual provenance is a landmark publication marking NPM as paradigm for perhaps two reasons. First, it introduced NPM as a comprehensive approach to the study of public administration and accounting, thereby un-covering a set of doctrinal how-to-getorganised techniques that could influence administrative practices (Hood, 1991; Hood and Jackson, 1991). Second, it advocated scrutinising the NPM theorising not only for its practical suitability but also for its normative reasoning based on administrative values (Hood, 1991, p. 10; also refer Hood and Peters, 2004). To substantiate NPM's theoretical reasoning, Hood (1991) advocated approaching 
the causal logic between administrative values and administrative design. Arising has been the NPM research program.

The NPM research programme created attention for the logical structure that relates three generic administrative values (frugality, rectitude, resilience) to administrative design, emphasising the complexity and contradictory nature of their relationships, like 'intersecting circles in a Venn diagram' (Hood, 1991, p. 15). Hood and Jackson (1991, p. 16) stress the need to reflect on the 'underlying theory of cause and effect' to enhance the explanatory power of NPM's generic concepts. The ambition to establish theoretical strength is indicated by adding disciplinary sources justifying NPM concept development, for example by taking a culturally informed view on how a reform actually matters (e.g. Hood, 1998). However, interdisciplinary can cause rivalry over theory, and as noted by Jacobs (2012; Jacobs, 2016), this has been a central concern of a recent debate on the usefulness of interdisciplinarity in PSA research.

Positioning PSA's role as a particular NPM-based research domain, as introduced by Hood (1995a), also influences choices of theory. NPM-based PSA research favours a contextual attitude (Broadbent and Guthrie, 2008; Jacobs, 2016). It relates to NPM's novelty as exhibited in reform programmes by referring resource costs concepts (e.g. Lüder and Jones, 2003) and their relationship to frugality (Hood and Dixon, 2016). It introduces a need to judge how NPM-based accounting systems come about in time and space. For modelling contextual assumptions (e.g. Broadbent and Guthrie, 2008, 1992), NPM-related PSA research is supposed to specify contextual boundaries for gaining better insights why accounting, budgeting or auditing reforms are different around the world (e.g. Lüder and Jones, 2003; Olson et al., 1998). The purpose is theory application by controlling for antecedent, perhaps context-sensitive effects, when comparing contextual settings or crossing levels of analysis (Whetten, 2009; Llewelyn, 2003). The complementary purpose is theory improvement from a context-specific explanation, especially by acknowledging the singularity and intrinsic nature of an observed institutional and/or organisational setting (Whetten, 2009; Keating, 1995).

For our interests, the most important issue raised by inaugurating NPM as a research program is the inherent problematisation of the interface between theorising about its generic concepts (e.g. frugality, resilience) and the theoretical ambition when applying them to NPM reform activities. Exploring NPM-related PSA research needs to account for the novelty of NPM's ontological reasoning and its relevance when referencing either the PA or the accounting research field. It also needs to account for the scope and relevance of conceptual and contextual assumptions suited to its subject matter, as it indicates theoretical alterations stemming from a shift in NPM's ontological emphasis.

\subsection{Exploring intellectual heritages for NPM-based PSA research: A bibliographic-based analysis}

The richness of NPM research becomes apparent when considering its disciplinary development. Synthesising efforts cover divergent subject domains (e.g. contemporary (N)PM and/or PSA research; Reiter and Klenk, 2019; Broadbent and Guthrie, 2008) as well as the case of theoretical pluralism when characterising the rationales introduced to justify the value of an inquiry. Divergent rationales 
have been mobilised to assess various states of NPM and/or PSA research. Broadbent and Guthrie $(1992,2008)$ proposed to distinguish between technical accounting, technical contextual accounting and contextually technical accounting as distinct patterns of PSA research. Their focus dealt with how perspectives on organisational contexts relate to the power of accounting to trigger change. There is also a literature addressing the nature of theory used in (N)PM/PSA research which applies classification schemes related to methodological considerations in social science research (e.g. Goddard, 2010; Jacobs, 2012) such as functionalism, interpretivism and radical/alternative. In light of such variety, we synthesised the qualitative, bibliographic-based PSA review literature addressing the early period of nascent theory building (see Table 1; covering 1992 up to 2008) to get a comprehensive view about the intellectual sources associated with post-1990 PSA research[3].

\section{BRING IN TABLE 1 ABOUT HERE}

As a catalyst for analysis and to organise the preliminary results, we explored three markers of theoretical reasoning as indicated by our referential (e.g. Jacobs, 2012; Broadbent and Guthrie, 2008) and methodological literatures (e.g. Llewelyn, 2003; Edmondson and McManus, 2007):

- Degree of theoretical sophistication when analysing PSA practice;

- Scope of multi-disciplinarity when theorising PSA practices; and,

- Criterion of assessing the theory-enhancing prospects of any PSA framing.

\subsubsection{Theoretical sophistication}

First of all, the bibliographic-based PSA review literature indicates a considerable body of PSA research that seems to make little inference, primarily claimed to be either purely descriptive or normative. Goddard's (2010) comparison reveals over $40 \%$ of papers used descriptive or normative approaches. This is consistent with Broadbent and Guthrie (2008) and Jacobs (2012) reasoning about the low degree of theoretical sophistication. However, van Helden (2005) put forward that about $70 \%$ of the papers studied in his review have used a 'general theory' as their source of inspiration (e.g. economics, neo-institutional sociology).

Strengthening theorisation may reflect the methodology specifically required to cope with an initial, even nascent, state of theorising. An instance of this may be well written-stories making sense of domain-specific phenomenon (Edmondson and McManus, 2007; Llewelyn, 2003). Gathering in-depth insights is judged as a precondition to problematise a phenomenon of interest: what makes accounting in a public service setting a distinct and interesting case for explication - sometimes called the surprising fact? One may note the concepts of Publicness (Steccolini, 2019) or Public Value Accounting (Moore, 1995, 2014) as such cases as they are presented as suitable metaphors distinct to Public Sector/Public Service Accounting. Building an appropriate domain theory that way is 
essential in order to uncover the indigenous core of PSA research (Humphrey and Scapens, 1996; Jacobs, 2012). Correspondingly, the issue of the scope of multi-disciplinarity is another aspect of theoretical reasoning to which we turn next.

\subsubsection{Multi-disciplinarity}

Within NPM-related PSA research, there are several perspectives and (multi-)method designs in use, appropriately categorised by common opposites of their methodological groundings (Riccucci, 2010; Llewelyn, 2003; Jacobs, 2012). In disciplinary terms, such heterogeneity becomes interesting because of the assumption that the singular framing is grounded in the initiating 'grand' or method theory: insights based on exploring domain-specific or context-sensitive phenomena go, preferably, beyond 'telling an empirically interesting story' and aim to find a way back to the scholarly conversation by refining or extending the mobilised concepts or propositions (Lukka and Vinnari, 2014, p. 1319).

The bibliographic-based literature reveals novelty from either borrowing or blending a method theory (see Table 1). By justifying that the scope of paradigmatic heritages increases over time, this literature indicates the step away from nascent to intermediate theory building in PSA research, as it identifies the presence of tentative explanations of NPM-related phenomena (Edmondson and McManus, 2007; Chandra and Walker, 2018). It also illustrates paradigmatic isolationism at the fieldlevel. This is substantiated by the visibility of epistemologically distinct and geographically dispersed research communities, primarily grounded in the uniqueness of their higher-level or general theory (van Helden, 2005; Goddard, 2010).

A more specific, second-level theorising by locating interdisciplinarity at the study level is largely absent (van Helden, 2005; Broadbent and Guthrie, 2008). Jacobs (2012; and discussion: Modell, 2013; Jacobs, 2013) explicitly highlights the tensions caused by borrowing or blending from a general or method theory: 'few if any papers' (Jacobs, 2012, p. 18) estimate the problem of commensurability and, equally important, what the research inquiry aims to challenge, the case or the theory. Modell (2013; Modell, 2017a) counters the risk of being eclectic in theory triangulation by suggesting critical realism as a paradigmatic grounding enabling the best explanation through alternative, perhaps antagonistic interdisciplinarity.

The epistemological part of the argument forces a scrutiny of the novelty and credibility assigned to a research inquiry relative to its disciplinary groundings, or the method theory. Some scholars (Lukka and Vinnari, 2014; Jacobs, 2013; Whetten, 2009) explicitly account for the need to problematise how insights are gained from contextual instead of conceptual assumptions and contextualising observations from the case. Such insights are compatible with borrowing a method theory when an inquiry aims to address the context-sensitivity of a proposition that refers to NPM-related PSA practices (Lukka and Vinnari, 2014), based on either a deductive (primarily theory-driven) or an inductive (especially phenomenon-driven) approach. 
Context-sensitive theorising about time and space is also of interest. For example, how does the novelty of a proposition that distinguishes context effects of PSA practices, e.g. their degree of publicness, challenge a prior domain-specific explanation, like NPM? Context-specific theorising emphasises the relevance of inquiries that scrutinise the NPM research programme itself because of observed PSA practices. 'Theorizing about context' (Whetten, 2009) this way reflects the evidence of a post-NPM discourse around the viability of the NPM template and/or PSA concepts therein (Pollitt, 2016; Steccolini, 2019). It emphasises theoretical improvements generated from understanding a context-sensitive phenomenon, perhaps stemming from the rivalry of Publicness or Public Value when addressing PSA (Bryson et al., 2014; Moore, 2014; Steccolini, 2019).

Enhanced mapping of such methodological reasoning is substantially in place (Modell et al., 2017b; Lukka and Vinnari, 2017; Richardson, 2018). The argument about domain-specific theorising and context effect theory is important for our research since it brings attention to the ontological shift associated with a post-NPM Public (Sector/Service/Value) Accounting framing. This necessarily emphasises the interface between the method theory and the domain-specific theorising applied (Lukka and Vinnari, 2014; Whetten, 2009). Notwithstanding, the effects of different paradigmatic premises remain a central concern within a research field characterised by interdisciplinarity.

\subsubsection{Reflexivity}

The third consideration relates to methodological choices in post-NPM PSA framing. Prescriptions on how to justify novelty in a domain-specific knowledge base are both crucial and, surprisingly, limited (Richardson, 2018; Whetten, 2009). Given the essential role of PSA interdisciplinarity (Jacobs and Cuganesan, 2014; Jeacle and Carter, 2014), our summary indicates a need to take greater account of the methodological fit. This is to adequately reflect prior theory building, by addressing either the state of nascent theorising or its maturity (Edmondson and McManus, 2007). Maturity is associated with two branches of intermediate theory building: domain-specific theorising of 'settings in context' as, for example, proposed from a critical realist point of view (Llewelyn, 2003; Modell, 2015b), and a distinctive path of 'grand' theorising, which is primarily concerned with framing the world of ideas (e.g. Habermas, Latour) rather than the world of practices (Modell et al., 2017b).

The above picture assists us in designing our complementary bibliometric analysis reported in the following section. Conducting bibliometrics should facilitate identification and evaluation of NPM's intellectual products by applying a structural and longitudinal perspective. Our synthesising prompts the need for careful substantiation of the development stages associated with the NPM template, at least because of its maturity. We started our macro-level analysis by differentiating two specific foci: first, we address evidence that locates PSA as a research domain within NPM's nascent period from 1991 to 2007; and second, we delineate the evidence about patterns of PSA research, given the intermediate period of NPM-based theorising from 2008 to 2018. 


\subsection{Substantiating the branching of NPM-based research: A bibliometric analysis}

\subsubsection{Bibliometric analysis: Methods and data management}

Discipline mapping using bibliometric methods is a tried and tested approach (Chen and Redner, 2010) particularly if there is a lack of clarity on the structure and development of a field, as is the case of NPM and its intersections with PA domains, such as PSA (Zupic and Čater, 2015; Curry and van de Walle, 2018). Bibliometric analysis of NPM is needed as it adds a quantitative dimension to the more qualitative, bibliographic-based PSA review literature discussed above (Zupic and Čater, 2015; Chandra and Walker, 2018; Alcaide-Muñoz et al., 2017). Aggregated bibliographic data can take several approaches including examining influence by measuring the most cited works (citation analysis) or similarity and structure when studying the frequency with which two units are cited together (co-citation analysis) (Pilkington, 2018; Pilkington and Meredith, 2009). In addition, dividing the data into multiple time periods captures the chronological emergence of the field (Zupic and Čater, 2015; Chandra and Walker, 2018).

In this study we apply citation and co-citation analysis to examine the emerging NPM template and explore the trajectory in intellectual structure through comparing two time periods: an early period of nascent theory building (1991-2007) and the later one of intermediate theory building (20082018). A wealth of bibliometric studies (e.g. Zupic and Čater, 2015; Chandra and Walker, 2018) provide clear evidence that this approach is ideal to address our interest in the macro-level[4]. Due to its structural and longitudinal perspective, citation/co-citation analysis identifies the most influential specific source titles in NPM research (termed as NPM's knowledge base, indicating the scope and depth of NPM research) and also the structural knowledge groups (referred to as NPM's intellectual structure), and thematic relationships between the sources, thereby indicating the disciplinary composition of NPM as a research field (Shafique, 2013; Pilkington and Meredith, 2009; Chandra and Walker, 2018).

In order to identify the structure and dynamics associated with the NPM template we used citation and co-citation analysis of articles with an explicit interest in NPM's initial core (Hood, 1991, 1995a) within the peer-reviewed journals available in the Social Science Citations Index (SSCl) as part of the Web of Science (WOS) database. We decided to address both articles because Hood (1991) promulgated NPM within the PA literatures (Chandra and Walker, 2018; Curry and van de Walle, 2018) and importantly Hood (1995a) brings NPM into the accounting literatures (Steccolini, 2019; Jacobs, 2016). Using both articles better addresses specialties occurring at NPM's intersection with PSA (Shafique, 2013; Chandra and Walker, 2018) and is one of several alternative strategies for compiling bibliometric data, e.g. searching for NPM as a keyword (Curry and van de Walle, 2018) or taking Hood (1991) per se (Chandra and Walker, 2018). In order to identify trajectories and shift we split the time date into early and late choosing 2008 as our break for three reasons: progressively increasing citations since 2008; a focus of arguments about the periods of NPM research within the literature, e.g. NPM paradoxes post-dating the 'middle aging' argument (Hood and Peters, 2004); and, the time periods covered by prior review articles (refer Table 1). By differentiating the period of 
intermediate NPM research we aim to add specific evidence to insights deriving from corresponding bibliometric NPM research (Chandra and Walker, 2018; Curry and van de Walle, 2018).

The data set was gathered from the SSCI (WOS) database which is a common accessed source of high quality data for bibliometric analysis (Pilkington, 2018; Zupic and Čater, 2015). The source data included the contents of any paper which cited either of Hood's seminal papers (1991, 1995a) as recorded in the SSCI (WOS) database. The data contained 2,016 source papers invoking 128,496 citations (see Table 2). It was converted into a standard format, checked for multiple versions of the same source, and also for different spellings and abbreviations of authors and journals. The data matrix covers source article information (e.g. publication information, author/s, titles, keywords); cross-linked to their standardised citations. The level of information contained in the standardised citations was first-named author, publication and publication year.

\section{BRING IN TABLE 2 ABOUT HERE}

As part of the data management, we evaluated whether there is a disciplinary coherence associated with NPM by looking at the age of what is cited-profile. Figure 1 shows the mean age of citation at around 12 years. This 12-year peak has also been exhibited in corresponding studies (Pilkington and Meredith, 2009; Córdoba et al., 2012) and gives confidence that there is no bias generated by a NPM-related citation habit.

\section{BRING IN FIGURE 1 ABOUT HERE}

\subsubsection{Results from citation analysis}

The citation analysis addresses the general focus of our bibliometric analysis: to identify how the NPM knowledge base has evolved since Hood (1991). Table 3 lists the Top-15 most frequently cited publications and source journals in absolute numbers and their resulting ranks across the period of analysis (1991-2018). The top 3 ranking (excluding Hood, 1991, 1995a) reveals an inaugural cluster of highly cited publications in the form of monographs rather than research articles (Osborne and Gaebler, 1992; Pollitt, 1990; refer also the editions of Pollitt and Bouckaert, 2000, 2004, 2011), all domiciled in the PA research field.

NPM is typically studied within a cluster of top-ranked PA journals (refer Table 2). Interdisciplinary imprinted accounting journals (e.g. Accounting, Organizations and Society, Accounting Auditing \& Accountability Journal; Critical Perspectives of Accounting) are coming close as the 2nd largest 
category and show a material engagement with NPM-related concepts (refer Table 3). The character of NPM as a growing and multi-disciplinary field is also indicated by citations from other non-PA areas, e.g. management or political science journals. This is largely similar to other bibliometric studies referencing the diffusion of the NPM template (Curry and van de Walle, 2018; Chandra and Walker, 2018).

\section{BRING IN TABLE 3 ABOUT HERE}

Due to the characterisation of NPM and PSA as research fields gaining distinct attraction across the globe (e.g. Goddard, 2010; Hood, 1995a), analysis of the citations per year within the basic stock of PA journals (European-based: Public Administration, Public Management Review [5], International Review of Administrative Sciences; U.S.-based: Public Administration Review, Journal of Public Administration Research and Theory) emphasises such a difference. Figure 2 illustrates NPM as being a topic of continuous and even volatile debate within the European sphere. The U.S.-based citation profiles indicate, at best, two waves of research, the latter starting, perhaps, with the opening of the post-NPM discourse from 2006, following.

\section{BRING IN FIGURE 2 ABOUT HERE}

It is notable that between the early (1991-2007) and the late period (2008-2018), the 'Most cited publications'-Figure is comparable. It indicates the necessity to carefully acknowledge the bias probably caused by the inaugural cluster of highly cited publications (see Table 4). We also note the upcoming interest in literature about theoretical (DiMaggio and Powell, 1983; Power, 1997) and methodological concerns (Yin, 1994), further indicated by changes in citation frequencies between the two periods (refer Figure 3).

\section{BRING IN TABLE 4 ABOUT HERE}

By adding this analysis, four observations are possible. First, the inaugural cluster of the NPM debate remained dominant as the focal reference, with an increasing interest in its intersection with PSA (Hood, 1995a). The continuity of the disciplinary NPM debate (Dunleavy and Hood, 1994; Niskanen, 1971 ) is specified by its frequently cited sources within the more recent discourse (e.g. Dunleavy et al., 2006). Second, a set of publications continued to be central within the discourse, thereby 
indicating a pattern of disciplinary reasoning according to the novelty of the NPM's research programme (e.g. Aucoin, 1990; Niskanen, 1971) and contingencies of practicing NPM reforms (e.g. Ferlie et al., 1996; Pollitt and Bouckaert, 2000, 2004, 2011). Third, the significance of the neoinstitutional approach, as indicated by prior systematic reviews, is mirrored in an increasing citation frequency of its essential publications: Meyer and Rowan (1977), DiMaggio and Powell (1983). A less obvious remark is Power (1997), suggesting attention to a sociological view and the Audit Society. The same goes, for example, with Moore (1995) or Rhodes (1997), because Public Value or Policy Networks provide rival concepts to study administrative practices. By contrast, an on-going 'marriage of opposites' (Hood, 1991) from sources associated with either economic theory (agency, transaction cost) or managerialism is not discernible. Fourth, sophistication beyond 'armchair theorising' (Broadbent and Guthrie, 2008, p. 146) is apparent from publications associated with a qualitative research methodology. Yin (1994) is one of the publications with the highest increasing citation frequency, supplemented by further sources to justify an interpretive research design (e.g. Eisenhardt, 1989). Publications indicating the use of quantitative methods are not as obvious, either with regard to their citation frequency or within the most cited items.

\section{BRING IN FIGURE 3 ABOUT HERE}

The citation analysis gives us preliminary insight into how the NPM knowledge base is composed: its generic idea; a scrutinising look on its novelty relative to its intellectual heritage(s) in PA; and, the scope of insights stemming from NPM reforms as they were practiced in specific government settings (for example, the UK public services/National Health Service; e.g. Ferlie et al., 1996; refer also Chandra and Walker, 2018).

A summary may claim that the mainstream of NPM-related research is primarily addressing the novelty and contextual antecedents of how NPM doctrines are applied, and thus revealing the pattern of contextualising NPM research (Broadbent and Guthrie, 2008; Steccolini, 2019). The epistemological emphasis might be interpreted as theory refinement: the exploitation of the NPM research programme is more focused on corroborating rather than contesting NPM's knowledge base. Additionally, missing nodes in our citation analysis are just as interesting. For example, when frugality is claimed to be a crucial administrative value (Hood, 1991; Hood and Dixon, 2016) it seems to be a caveat of NPM-related research when mechanisms of accounting or budgeting are not present as a distinctive topic covered by NPM's highly acknowledged research outcomes. In contrast to PSA-evidence associated with citations in accounting journals, a coherent node associating PSA themes within NPM is not discernible.

We qualify the above with two considerations: first, contextualising NPM research presents a distinct research domain but when examining PSA research the contribution of NPM knowledge remains 
vague. Second, citation analysis places importance on influential knowledge nodes without considering their positioning relative to each other over time. Thus, we turn to evidence drawn from co-citation analysis aiming to corroborate (or challenge) presumptions around the patterns of scholarly knowledge development.

\subsubsection{Results from co-citation analysis}

Having identified a contextualising NPM research imprint, the co-citation analysis aims to identify what structural knowledge groups reveal about NPM-related research. A structural knowledge group is constituted when a set of references tend to be frequently associated. A highly co-cited publication may be a major contributor to a knowledge group even when it is not frequently cited. Bibliometric analysis imagines that the set of these groups, and the relationships among them, constitute the intellectual structure of a research field (Pilkington, 2018; Zupic and Čater, 2015).

As the referential map of our analysis, Figure 4 exhibits all co-citations across 1991 to 2018, whereas Figures 5 and 7 illustrate the intellectual structure of each sub-period[6]. Similar to citation analysis, the graph displays the inaugural core (Hood, 1991; Pollitt, 1990; Osborne and Gaebler, 1992) and the realm of neo-institutionalism (DiMaggio and Powell, 1983; Meyer and Rowan, 1977) which differs from theorising the Audit Society (Power, 1997). A further cluster indicates the empirical side of contextualising NPM research, by focusing NPM 'in action' (Ferlie et al., 1996) without supposing that comparative NPM research (e.g. Pollitt and Bouckaert, 2000, 2004, 2011) is highly coherent, as a cociting network. As distinctive fractions, the main intellectual branches reflect NPM's knowledge base, as identified above. By contrast, Figure 4 also exhibits a broad set of singular ties associated with Hood (1991) indicating heterogeneity rather than coherence or continuity as a central concern in assessing NPM's intellectual structure. Notable is Hood (1995a) as the singular node, representing the link to accounting literatures, invoked neo-institutionalism, Audit Society and, interestingly, the qualitative research methodology.

\section{BRING IN FIGURE 4 ABOUT HERE}

\section{Nascent theory research: The early period 1991-2007}

Figure 5 displays a more detailed view of NPM's initial disciplinary step. The early period has two major clusters, of course including the inaugural publications. The second cluster, covering Hood (1991), Pollitt (1990) and Aucoin (1990), evidences debate about paradoxes triggered by the NPM idea. The diagram also illustrates some thick ties associated with this topic, as for example further critical reasoning by the inaugurating authors (Dunleavy and Hood, 1994; Hood, 1995a). Additionally, assessing NPM's novelty is indicated only by some singular ties: its position relative to bureaucracy (Niskanen, 1971), the role of political institutions (March and Olsen, 1989), or how governance matters (Rhodes, 1997). Given the time span suited to nascent theory building (1991-2007), again the 
Notwithstanding this notation, Figure 6 partly illustrates nascent research inquiries behind the scene, similarly to Figure 8 (Late: 2008-2018) and Figure 9 (All: 1991-2018). These figures enhance the cocitation map by cutting off the top and removing both the most frequently and the rarely cited references. It presents a second layer of bibliometric analysis by grouping topics not visible before because the first layer diagrams (Figure $4,5,7$ ) were dominated by the inaugural cluster[7].

In the early period there are two distinct clusters differentiating NPM research programme discussions into theoretical and practical branches, primarily triggered by Pollitt and Bouckaert (2000) and Aucoin (1990) (see Figure 6). Assessing theoretical relevance is represented by positioning its novelty, in particular by referencing the 'old' PA (e.g. Niskanen, 1971; Dunleavy and Hood, 1994). Elements of practicality are seen when explaining the scope of NPM reforms. This is substantiated by sources conducting comparative research, as exhibited by Christensen and Lægreid's (2001) conclusions about NPM-related reform activities. The distinct cluster on the left hand side is more associated with complexity induced by transforming NPM into practice (e.g. Ferlie et al., 1996), in particular with a focus on contextual receptivity when explaining the variability of NPM initiatives in the UK National Health Service. Notable is also the inner circle primarily triggered by Hood (1995a), again linked with theorising the Audit Society (Power, 1997).

\section{BRING IN FIGURE 6 ABOUT HERE}

Intermediate theory research: The late period 2008-2014

NPM's disciplinary path, marked by a more mature state, is shown in Figure 7. Again, the dominating role of the inaugural core is formative (but with decreasing relevance of Pollitt, 1990; it is replaced by Pollitt and Bouckaert, 2004), and the relevance of neo-institutionalism and Audit Society research is enduring, as shown by the visibility of their origins. Increased theorisation becomes present in methods (Yin, 1994) and conceptualisations so some thick ties connect with Public Value Management (Moore, 1995) and New Public Governance (Osborne, 2006). Within the post-NPM discourse, both perspectives are valued as complementary narratives for theorising the relationship between administrative values and design (Bryson et al., 2014; Steccolini, 2019). 


\section{BRING IN FIGURE 7 ABOUT HERE}

Figure 8 presents the second layer and substantiates the ways that theorisation extended via altered scope of domain-specific problems, concepts and perspectives. It shows Public Value Management (e.g. Moore, 1995; Stoker, 2006) and New Public Governance (Osborne, 2006) as important domainspecific perspectives. A complementary subject, not visible so far, is the greater attention for the individual level: Public Service Motivation (e.g. Perry and Wise, 1990). Yet, framing NPM from neoinstitutionalism remains and adds intriguing concepts around antecedents of strategic responsiveness (e.g. Oliver, 1991). The 'middle aging' debate (Hood and Peters, 2004) becomes observable, interestingly linked with recent PSA reviews (e.g. Lapsley, 2008; Broadbent and Guthrie, 2008). A critical perspective on accounting information use is also present (e.g. Kurunmäki, 2004). Similarly, it indicates the value of extending the scope of NPM knowledge, also by emphasising an individual level-concept: the calculative expertise of medical professionals.

A further notable point identifies Governance of Policy Networks as a cluster providing an institutional-descriptive and historical-comparative view on NPM-related reform in context. This constitutes a distinctive research pattern, primarily emphasising the relevance of a domain-specific, context effect theory (Lukka and Vinnari, 2014; Whetten, 2009). Distinctiveness is created by its farreaching reference to the 'Westminster model' as an organising perspective or map of the subject. Together with its positioning at the intersection of political science and public administration, a reflexivity in defending and re-defining an institutional-approach derives from studying the British government and its (administrative) politics (Rhodes, 1997; Newman, 2001).

\section{BRING IN FIGURE 8 ABOUT HERE}

\section{Going across time: $A$ view on the schooling of the NPM research programme}

In contrast to Figure 4, where the overall co-citation map suggests only weak groupings within NPM's intellectual structure, Figure 9 presents observations again by cutting off the top. The graph displays the branching of the NPM knowledge base by identifying its separate, more domain-specific knowledge groups and, therefore, intellectual sources available for PSA research.

Figure 9 indicates the pattern of contextualising NPM research as ongoing. Indications of the pattern are found in debates of novelty (e.g. Niskanen, 1971; March and Olsen, 1989), and by research efforts addressing the NPM reform context (e.g. Christensen and Lægreid, 2001). More interesting are extensions to the NPM knowledge base and their various pathways. Public Value Management (Moore, 1995; Stoker, 2006) and New Public Governance (Osborne, 2006) introduce, perhaps partly, distinct perspectives by redefining the subject(s) of NPM's interest. By contrast, the concept of 
Governmentality (e.g. Miller and Rose, 1990) references Foucault, thereby extending the NPM and/or PSA knowledge base by applying a 'grand' or method theory (Jacobs, 2012; Lukka and Vinnari, 2014). Addressing the individual level also reframes the subject of interest, by adding a motivational (Perry and Wise, 1990) or critical lens (Kurunmäki, 2004). But apparently, these re-framings are not linked to the debates about New Public Financial Management (Olson et al., 1998) or the more recent Public Service Accounting (Broadbent and Guthrie, 2008).

\section{BRING IN FIGURE 9 ABOUT HERE}

In sum, our evidence demonstrates that the NPM knowledge base, when considered as a field of domain-specific theorising (Lukka and Vinnari, 2014), is composed of a set of referential concepts around its disciplinary inauguration. Decomposing the intellectual structure of the NPM realm by bibliometric methods is of value for proving (or refining) the specialties of the referential subject matter and how it is framed for post-1990 PSA research. When extending the bibliometric analysis by exploring the intellectual structure for patterns of inquiry and effects of disciplinary branching behind the scene and across the periods, it becomes meaningful to account for disciplinary fragmentation (Abbott, 2001) and also the interface between theory and context (Whetten, 2009; Broadbent and Guthrie, 2008).

The most striking issue is the evidence of Governance (Rhodes, 1997; Osborne, 2006), Public Value (Moore, 1995; Stoker, 2006) and, more recently, Public Service Motivation (Perry and Wise, 1990) as domain-specific conceptualisations. From the literature, we may add Publicness (Steccolini, 2019) or Governmentality (Jacobs, 2012) as complementary, especially as both address the generic nature of PSA. Their appearance as 'theories of context' (Whetten, 2009) and scholarly references indicates the necessity to further substantiate post-NPM's novelty as a context-sensitive research programme. This is by strengthening the role of time and space in contributing to post-NPM theorising, primarily signified by restating the role of the 'Westminster model' (e.g. Rhodes, 1997; Newman, 2001). In a similar vein, authors like Moore (2014) and Steccolini (2019) scrutinise the post-1990 PSA theorising about its subject, thereby acknowledging the need for disciplinary intersections (e.g. ethics, political science) to establish post-NPM PSA perspectives. The path of exploration considers novelty by explicitly introducing such frames to explore the contextual distinctiveness of phenomena observed in PSA practices (e.g. deontological value, publicness, policy networks, rituals of verification).

The continuity of addressing the context specifity (McKinley et al., 1999) of how NPM reforms are applied is also nuanced. The relevance of borrowing from organisational, managerial or other intellectual heritages becomes visible in neo-institutionalism and, recently, Governmentality drawn from Foucault, as was similarly indicated by prior literatures. Notable, and in contrast to bibliographic insights addressing PSA's borrowing from 'grand' method theories (Jacobs, 2016; Goddard, 2010), is 
an absence of evidence for any further NPM-related branching, for example based on ANT or Habermas.

To overview our findings: we have identified NPM as a domain-specific research programme with relevance to post-1990 PSA research outputs, not least because of the essential frugality-argument. Within that oeuvre our analysis of the bibliographic-based PSA literatures revealed three aspects of post-1990 PSA research: some weaknesses in theoretical sophistication; the presence of multidisciplinary; and the need for reflexivity. Most notable from our bibliometric analysis are the distinct patterns of inquiry and the branching effect generating disciplinary fragmentation as analysed in Figures 4 to 9 . With those findings in mind, we turn to a discussion which aims to develop an 'inquiryheritage' matrix for better understanding the variety of pathways for substantiating and extending the novelty of post-NPM PSA research.

\section{Discussion: Positioning a Public Sector Accounting inquiry within the New Public Management knowledge base (or its follow ups)}

The central concern of this paper is to reflect on NPM as theoretical grounding for post-1990 PSA research, without being deflected by controversial claims about a need of NPM 'redux' in the postNPM debate (Pollitt, 2016; Steccolini, 2019). When taking the NPM knowledge base as reference, its schooling seems to leave us with a weak setting of consistent research domains, primarily indicated by the referential map outlined in Figure 4 . At best, the figure reflects the discourse around NPM's novelty and the realm of neo-institutionalism as two distinctive fractions of its disciplinary development. What makes the inference preliminary and crucial for any post-NPM debate is the invisibility of disciplinary fragmentation, as indicated by our second layer analysis. Encountering disciplinary fragmentation is indeed the most interesting insight and of value, since it calls for refining our thinking about post-1990 PSA theorisation. Thus, the 'redux'-argument about NPM's continuity appears to be antithetical to novelty and the emancipation of PSA scholarship within the post-NPM debate. Creating novelty reflects upon the relevance of context-sensitivity in post-NPM theory building (e.g. publicness, public value, policy networks) and why interdisciplinarity should be considered as a rewarding source for re-framing post-1990 PSA theorisation. To render this argument valuable, we proceed with developing and positioning it against our empirical evidence.

Even at its birth, Hood's (1991) prescriptive reasoning about NPM as research programme drew attention to the relationship between the phenomenon of interest, e.g. the context-sensitivity of administrative values as the 'public' side of NPM, and the relevance and suitability of disciplinary sources. Hence, positioning the intellectual heritages of theorising in post-1990 PSA research is important. The argument is signified by Hood's (1991) notation of the paradoxical nature of exploring NPM's 'public' origins when considering the value interfaces of frugality, rectitude and resilience. Correspondingly, our bibliographic analysis indicates the scope of disciplinary sources suitable to justify the logic of inquiry in PSA research. Bringing both arguments together reveals a twodimensional 'inquiry-heritage' matrix as a categorisation scheme[8] appropriate to further describe prospects of discovering cumulative knowledge in post-NPM based PSA research. 
To arrive at Table 5, we conceptualised the two dimensions as being: first, definitions of the topic of interest labelled as research inquiry; and, second, patterns of grounding PSA theorisation labelled as epistemological heritage. In terms of theory building, these dimensions are consistent with considerations of domain and method theory (Lukka and Vinnari, 2014; Lukka, 2005). Moreover, delving into a typological frame is complementary to Richardson's (2018) taxonomical approach to further categorise the value of strategies for generating cumulative knowledge (Parker et al., 2019), and it may be useful in coping with the apparent risk of 'monopolized scholarly attention' (Steccolini, 2019). By elaborating this scheme, we aim to categorise the empirically based patterns of inquiry as primarily identified by our bibliometric analysis. The patterns are synthesised by profiling them as distinct but theoretically grounded types of inquiry, which also entails a different view on the value deriving from disciplinary fragmentation.

\section{BRING IN TABLE 5 ABOUT HERE}

In Table 5, the columnar dimension considers disciplinary sources useful to strengthen the propositional research outcome that derives from exploring a phenomenon, hence the domainspecific case. It addresses what type of theoretic contribution an inquiry aims to constitute, thereby covering the differentiation between theory discovery, theory refinement or reinforcing, and theory re-imagining (Keating, 1995; Lukka, 2005; Jack et al., 2013). Jack et al. (2013) introduced theory reimagining as a perspective to address the specialties of exploring a historically and politically dominated context. Distinguishing the various roles that an inquiry may take is a meaningful way to demonstrate why a contribution may be a significant advancement and novel within a research area.

For each of the columnar sub-categories in Table 5 we can apply questions regarding research outcomes: what is?; what is new?; and, what is different?. These outcomes implicate various kinds of theorisation. Borrowing is a metaphor to distinguish whether a what is new? inquiry relies on a preselected theoretical approach, or learns from domain-specific insights for 'grand' theorising. Blending considers the case of re-imagining what is different? by using rival explanations to enhance the explorative power of the domain-specific case or problem. Notwithstanding, specific challenges may be constituted by any theoretical triangulation (Modell, 2013, 2015a). Counter to 'armchair theorising' as identified by Broadbent and Guthrie (2008), the scheme also presumes the discovery role of a what is? research design, since it introduces the relevance of generating first-order inferences as context-sensitive metaphors, concepts or propositions (Llewelyn, 2003; Eisenhardt, 1989). Distinguishing what is? research acts to value narrative descriptions and the challenge of substantiating their methodology as a well-recognised but weakly synthesised field of inquiry. Mobilising intellectual heritage(s) that way entails how theory-enhancing inferences occur from the domain-specific case, hence the epistemic positioning of a context-sensitive exploration of the phenomenon of interest. 
The rows in Table 5 are concerned with the substantive topic of PSA theorisation, or why a domainspecific fact is surprising and worthy of being claimed as a contribution to scholarly knowledge. We label this research inquiry as it relates to the relevance of contextualisation as a theory-enhancing effort, and how it affects the methodological grounding of an inquiry.

Initially, Broadbent and Guthrie (1992) distinguished between context-free (technical accounting), context-bound (technical contextual accounting) and context-specific (contextually technical accounting) kinds of PSA-related theorising. Their argument reflects the necessity to carefully assess the value of investigating effects of contextualisation, especially by acknowledging the context effects from time and space for explaining the distinctiveness of PSA practices (Whetten, 2009; Jack et al., 2013). Extending, a PSA research inquiry can be labelled domain-specific if it, for example:

- addresses a context-sensitive problem, especially when the idea or insight is used to differentiate the meaning and uniqueness of concepts describing PSA practices, as shown by Steccolini's (2019) argument about Publicness;

- demands to incorporate context-sensitive factors and effects, even when antecedents count for variances in reform trajectories, processes or outcomes, as exemplified by the contextual receptivity when NPM is in action (Ferlie et al., 1996); or

- requires a context-specific explanation that aims to understand and explain a local phenomenon, as illustrated by Rhodes (1997) reasoning around NPM-related UK reforms and their role for restating the 'Westminster model' of governance.

Bibliometric analysis of the intermediate NPM-based research illustrates the relevance of reflecting the domain-specific point of reference for PSA research (e.g. publicness, public value, public service motivation when addressing different levels of analysis). This is closely linked to the argument of being attentive to the ontological shift introduced by a post-NPM inspired PSA discourse (Steccolini, 2019). Further exploration of how to generate such context-sensitive PSA theory may yet yield an additional and valuable path of reasoning to enhance the rigor of re-framing post-1990 PSA research, as for example discussed in management science (Jack et al., 2013; Whetten, 2009).

The 'inquiry-heritage' matrix may substantiate interdisciplinarity in post-NPM PSA research when valuing it as a comprehensive way to fit ontological complexity with epistemological sophistication. The notion is associated with the requirement to distinguish one's interest as either an inquiry as to what is?, or what is new or different?. It also specifies ways to meet the subsequent challenge of methodological fit (Edmondson and McManus, 2007). For this purpose, we emphasise five combinations inspired by our evidence to gain intellectual sources for subsequent research [9].

When considering the attractiveness of intellectual sources and the level of contextualisation addressed by an inquiry, the matrix identifies a first typical case, which we label (a) bounded midrange, indicating a methodological frame that explores contextual or conceptual boundaries placed by an endogenous concept (or proposition) that derives from a single source of theorising, simply named as borrowing. In contrast to theory illustration (Humphrey and Scapens, 1996; Lukka, 
2005), theory development is directed towards using the contextual difference to enhance referential 'grand' or method theory (Lukka and Vinnari, 2014). In our terms, it explains why a referential knowledge domain, e.g. neo-institutional theorising, needs to be refined because of such insights. Our evidence indicates the need to account for the bounded midrange type as a meaningful template for PSA inquiries.

Moving to the second combination, the (b) ethnographic type is preconditional to substantiate what is different, notwithstanding methodological challenges of displaying the inquiry's rigor, beyond its anecdotal evidence. Theory discovery in post-NPM PSA inquiries is faced with how to reach a sufficient proof of the inference. Perhaps this could stem from grounded theory building or strengthening interventionist case research (e.g. Lukka and Vinnari, 2017), or by synthesising a phenomenon-driven approach to accounting narratives (e.g. von Krogh et al., 2012).

Taking the prospects of phenomenon-driven insights as a reference, it may be contrasted by an extended, domain-specific theory as it delivers in-depth, but even differential, insights about the context-sensitivity of a concept or theory arising from case(s). Intriguing examples of this arise in the (c) domain-specific type and challenges the NPM concept of governance in its contextual relation to the 'Westminster model' (Rhodes, 1997) or in shifting to its Publicness (Steccolini, 2019). Post-NPM's novelty may match with this type when we consider the rivalry of concepts deriving from NPM's intellectual structure (e.g. Public Value, Public Governance) combined with their contextualisation, hence the assessment of post-NPM reform activities.

The two final types are more conclusive than empirically evident, but both incorporate tensions caused by the challenge of blending rival epistemological approaches. The (d) local strategy type is concerned with the building blocks of informing theories that may constitute study-level interdisciplinarity, perhaps by using critical realism as an epistemological reference for justifying the assimilation of cross-disciplinary insights (O'Dwyer and Unerman, 2014; Modell, 2017a). In contrast, the 'transformation of coalitions of complementary perspectives' (O'Dwyer and Unerman, 2014, p. 1228 ) is scrutinised by Jacobs' (2012) sober reasoning on the evidence: 'Few if any papers explicitly considered the epistemological and ontological underpinnings of the theories used.' Given such mixed messages and the first stirrings of study-level interdisciplinarity (e.g. Wiesel et al., 2011), the notable point is a recently renewed debate about the use of theoretical triangulation as an epistemic approach for PSA inquiries (e.g. Parker and Guthrie, 2014; Modell, 2015b). Our framing makes the additional point that study-level interdisciplinarity is supported by both the ethnographic and bounded midrange type. This is because they may deliver stepping stones for assessing the essential insights from the historically dominated case, especially for contextualising rival method theories.

Finally, the (e) polymath type refers to field-level interdisciplinarity, not only as a peculiar feature of a research domain (Goddard, 2010; O'Dwyer and Unerman, 2014), but as a distinct research problem for post-NPM and PSA research when strengthening the dialogue with other disciplines (Steccolini, 2019; Jacobs, 2016). Differentiating this type is concerned with contradictions: one that goes with institutional risks of doing such interdisciplinary research (Endenich and Trapp, 2018), and one that 
goes with the methodology useful for appreciating the rivalry of domain or method theories (Modell et al., 2017b). However, a candidate for strengthening the endeavour may be further theorising the 'chaos of disciplines' (Abbott, 2001), and the relevance of fractal distinctions for distinguishing either 'grand' or contextualised theorisation in post-NPM PSA research.

The matrix is helpful to scrutinise ideas promising an all-purpose methodological garment, such as interdisciplinarity and theoretical plurality for a post-NPM context. The popularity of being interdisciplinary needs to be reflected when we consider the evidence from this study. As mentioned by Jacobs (2013), at the 'heart of the problem' of interdisciplinary PSA theorising we have two modes of reasoning: whether the case is used to substantiate the theory (borrowing from theory), or whether the theory is used to substantiate time and space of an intrinsic case (by blending theories). Similarly, Steccolini (2019; refer also Jacobs, 2012) suggested to start post-NPM PSA research with either exploiting domain-specific lenses different to NPM or exercising abstractions from public service practices. As compared to such debate, the reasoning depicted in the 'inquiry-heritage' matrix introduces a complementary point of departure. This is especially when assessing the relevance and value of context-sensitive contributions from post-1990 PSA research. If it is claimed that interdisciplinarity is the most suitable path for reinventing the PSA research domain, attention is needed in moving from one type of inquiry to the another in the matrix.

\section{Conclusions, limitations and further study}

NPM and its value as an intellectual heritage for scholarly efforts in post-1990 PSA is contested terrain. It attracts scholarly attention because understanding NPM's role as a tributary to post-1990 PSA is a vital effort to emancipate PSA scholarship after NPM. Therefore, delivering a helicopter view of its achievements and substantiating the fragmentary nature of research about NPM is specifically useful for PSA scholars wishing to depart from the 'monopolized scholarly attention' (Steccolini, 2019) created by NPM.

Primarily based on our bibliometric analysis, we conclude that: (1) the most intriguing insight is NPM's branching and disciplinary fragmentation; (2) the scope and continuity of NPM's research domains become more visible when analysed in the absence of the seminal NPM papers, as illustrated by our co-citation analysis behind the scene; and, (3) further understanding of disciplinary perspectives for post-NPM PSA may result from exploiting the 'inquiry-heritage' matrix. Our analysis suggests that exploring NPM as a disciplinary grounding for post-1990 PSA creates a rewarding source for re-framing the subject of PSA scholarship and its interdisciplinarity. This is not to argue that PSA research has only been influenced by NPM concepts but our study identifies some of the NPM influences whilst confirming that NPM conceptualisation did influence PSA research.

The fragmentary nature and heterogeneity of NPM's knowledge base reveals a specific argument and complementary point of departure when discussing the intersection of post-NPM and PSA. It is necessary to distinguish the novelty introduced by post-NPM theorising (for example from either PA or public policy studies). Similarly, positioning the relevance and value-add from contextualised PSA 
inquiry is a desirable outcome from reflection on the results herein. By translating these insights into prospects of post-NPM related PSA theorising, the paper develops the 'inquiry-heritage' matrix (refer Table 5) for two purposes: first, as a typological approach at the field-level launched to describe and distinguish epistemological sources and pathways of disciplinary development from post-1990 PSA research; and, second, as a means to characterise and juxtapose the novelty of the intellectual product and its theoretical contribution that a PSA research inquiry aims to deliver to its origin, being it either a method or domain theory.

The insights from this research are data-informed, mainly from the bibliometric method applied. However, they remain exploratory. Limitations arising need to be considered and further research for qualitative generalising can be discerned (Parker and Northcott, 2016), as is done below.

In terms of limitations, the study acknowledges that sampling bibliometric data can be rather blunt. Reasoned citation may be confounded by strategic citations (Pilkington, 2018; Zupic and Čater, 2015), perhaps explaining why our insights primarily occur from identifying the effects of disciplinary fragmentation. Co-citations are not easily captured, especially when highly cited publications remain strongly visible over time. Additionally, whilst bibliometric studies are naturally based on developing time series, they must acknowledge that institutional settings over time are not fixed. Observable tightening of journal-rankings and institutional reward systems are impacting on publication metrics (Meyer et al., 2018; Endenich and Trapp, 2018). Thus, further research is justified.

In terms of further research, a number of avenues to increase the credibility of our research present themselves. A follow-up study may explore the relevance of institutional impediments for theorybuilding efforts, perhaps grounded in social network analytics for advanced bibliometric methods. This anticipates the institutional and political nature of scientific work, where the latter is associated with the social influence assigned to a journal within a bibliometric environment (Rost et al., 2017; Endenich and Trapp, 2018). Further reasoning may assimilate such insights, particularly when one aims to compare knowledge accumulation with reference to different, even multi-disciplinary research fields (Wright, 2011; Richardson, 2018). From our analysis, an additional avenue for further research may be found in refining the propositional arguments about NPM's survival, especially given speculation about 'managerialism redux' (Pollitt, 2016; Reiter and Klenk, 2019). Exploring changes of intellectual heritages like NPM by tracking growth areas from a macro field-level perspective (Small, 2006) may also be interesting for sustaining and refining our results. There may also be value in considering complementary intellectual sources that change each other, e.g. the 'chaos of disciplines' (Abbott, 2001), and how subsequent clusters create dynamics in scientific developments, which may be revealed through citation network analysis (Chandra and Walker, 2018). Consequently, conceptual work is also required for a finer-grained typological theorising (Cornelissen, 2017).

\section{Final remark: looking back in order to look forward}

This study reveals the opportunity of PSA research to advance theory-based understanding of what constitutes the discipline. Inquiries should look back to PSA's origins to know more about its 
prospects. Social science knowledge does not escape the condition that knowledge is socially constructed, so as an idea gathers more consensus it risks no longer being subject to critical analysis - indeed, even being read? Tracing the seminal work of notable scholars could be insightful for the use of literatures' themes to introduce topics, theories, and research programmes.

From our research, discerning NPM's relationship to PSA is problematic. This may be continuing and so extending the understanding of PSA and prospects of its interdisciplinarity becomes more timely. There is a need to identify specific considerations of PSA with their connections to NPM, thereby emphasising the contextual or domain-specific characteristics of new waves of public sector reform. For example, it is plausible that managerial accounting with its focus of resource-cost and other aspects of frugality that are hallmarks of NPM will have exhibited different concerns than financial accounting research with its concerns of accountability and governance.

Standing back from the myriad of research projects, findings, citations, and co-citations so as to view a discipline as an entity, albeit multifaceted, may provide our best chances of identifying epochs of research and social realities. The 'inquiry-heritage' matrix as proposed in this study may be a useful compass to guide the journey. Arising, we argue that NPM as a contextual and, therefore, conceptual device continues to breathe; further, post-NPM PSA will be validly accorded the role of an enabling device to past and current programs of public sector reform. Like all social science, the influence of NPM research on PSA will not be stable so interested researchers would do well to 'watch this space'. 


\section{Appendix A: Abbreviations}

\begin{tabular}{|l|l|}
\hline AAAJ & Accounting, Auditing and Accountability Journal \\
\hline AAR & Australian Accounting Review \\
\hline AF & Accounting Forum \\
\hline ANT & Actor-network theory \\
\hline AOS & Accounting, Organizations and Society \\
\hline BAR & British Accounting Review \\
\hline CPA & Critical Perspectives on Accounting \\
\hline EAR & European Accounting Review \\
\hline FAM & Financial Accountability and Management \\
\hline IRAS & International Review of Administrative Sciences \\
\hline JAPP & Journal of Accounting and Public Policy \\
\hline JPBAFM & Journal of Public Budgeting, Accounting and Financial Management \\
\hline JPART & Journal of Public Administration Research and Theory \\
\hline MAR & Management Accounting Research \\
\hline NPM & New Public Management \\
\hline NPFM & New Public Financial Management \\
\hline OS & Organization Science \\
\hline PA & Public Administration (the discipline) \\
\hline PubAdm & Public Administration (the journal) \\
\hline PAR & Public Administration Review \\
\hline PBB & Performance-based Budgeting \\
\hline PSA & Public Sector Accounting \\
\hline RGNPA & Research in Governmental and Non Profit Accounting \\
\hline & \\
\hline
\end{tabular}




\section{References}

Abbott, A.D. (2001), Chaos of disciplines, University of Chicago Press, Chicago.

Acedo, F.J., Barroso, C., Casanueva, C. and Galan, J.L. (2006), "Co-Authorship in management and organizational studies: An empirical and network analysis*", Journal of Management Studies, Vol. 43 No. 5, pp. 957-983.

Alcaide-Muñoz, L. and Rodríguez Bolívar, M.P. (2015), "Understanding e-government research: A perspective from the information and library science field of knowledge", Internet Research, Vol. 25 No. 4, pp. 633-673.

Alcaide-Muñoz, L., Rodríguez-Bolívar, M.P., Cobo, M.J. and Herrera-Viedma, E. (2017), "Analysing the scientific evolution of e-Government using a science mapping approach", Government Information Quarterly, Vol. 34 No. 3, pp. 545-555.

Anessi-Pessina, E., Barbera, C., Sicilia, M. and Steccolini, I. (2016), "Public sector budgeting. A European review of accounting and public management journals", Accounting, Auditing \& Accountability Journal, Vol. 29 No. 3, pp. 491-519.

Aucoin, P. (1990), "Administrative reform in public management: Paradigms, principles, paradoxes and pendulums", Governance, Vol. 3 No. 2, pp. 115-137.

Broadbent, J. and Guthrie, J. (1992), "Changes in the public sector: A review of recent "alternative" accounting research", Accounting, Auditing \& Accountability Journal, Vol. 5 No. 2.

Broadbent, J. and Guthrie, J. (2008), "Public sector to public services: 20 years of "contextual" accounting research", Accounting, Auditing \& Accountability Journal, Vol. 21 No. 2, pp. 129-169.

Bryson, J.M., Crosby, B.C. and Bloomberg, L. (2014), "Public Value Governance. Moving beyond traditional Public Administration and the New Public Management", Public Administration Review, Vol. 74 No. 4, pp. 445-456.

Chandra, Y. and Walker, R.M. (2018), "How does a seminal article in Public Administration diffuse and influence the field? Bibliometric methods and the case of Hood's "A Public Management For All Seasons?"”, International Public Management Journal, Vol. 103 No. 4, pp. 1-31.

Chen, P. and Redner, S. (2010), "Community structure of the physical review citation network", Journal of Informetrics, Vol. 4 No. 3, pp. 278-290.

Christensen, T. and Lægreid, P. (Eds.) (2001), New public management: The transformation of ideas and practice, Aldershot, UK: Ashgate.

Christensen, T. and Lægreid, P. (Eds.) (2007), Transcending new public management: the transformation of public sector reforms, Ashgate Aldershot.

Córdoba, J.-R., Pilkington, A. and Bernroider, E.W.N. (2012), "Information systems as a discipline in the making: Comparing EJIS and MISQ between 1995 and 2008", European Journal of Information Systems, Vol. 21 No. 5, pp. 479-495.

Cornelissen, J. (2017), “Editor's comments: Developing propositions, a process model, or a typology? Addressing the challenges of writing theory without a boilerplate", Academy of Management Review, Vol. 42 No. 1, pp. 1-9. 
Curry, D. and van de Walle, S. (2018), "A bibliometrics approach to understanding conceptual breadth, depth and development: The case of New Public Management", Political Studies Review, Vol. 16 No. 2, pp. 113-124.

DiMaggio, P. and Powell, W.W. (1983), "The iron cage revisited: Collective rationality and institutional isomorphism in organizational fields", American Sociological Review, Vol. 48 No. 2, pp. 147-160.

Dunleavy, P. and Hood, C. (1994), "From old public administration to new public management", Public Money and Management, Vol. 14 No. 3, pp. 9-16.

Dunleavy, P., Margetss, H., Bastow, S. and Tinkler, J. (2006), "New public management is dead--Long live digital-era governance", Journal of Public Administration Research and Theory, Vol. 16 No. 3, pp. 467-494.

Edmondson, A.C. and McManus, S.E. (2007), "Methodological fit in management field resesearch", Academy of Management Review, Vol. 32 No. 4, pp. 1155-1179.

Eisenhardt, K.M. (1989), "Building theories from case study research", Academy of Management Review, Vol. 14 No. 4, pp. 532-550.

Endenich, C. and Trapp, R. (2018), "Signaling effects of scholarly profiles - The editorial teams of North American accounting association journals", Critical Perspectives on Accounting, Vol. 51, pp. 4-23.

Ferlie, E., Ashburner, L., Fitzgerald, L. and Pettigrew, A. (1996), The new public management in action, Oxford University Press, Oxford, New York.

Goddard, A. (2010), "Contemporary public sector accounting research-An international comparison of journal papers", British Accounting Review, Vol. 42 No. 2, pp. 75-87.

Hood, C. (1995a), "The "New Public Management" in the 1980s: Variations on a theme", Accounting, Organizations and Society, Vol. 20 No. 2, pp. 93-109.

Hood, C. (1991), "A public management for all seasons", Public Administration, Vol. 69 No. 1, pp. 319.

Hood, C. (1998), The art of the state: Culture, rhetoric, and public management, Oxford University Press.

Hood, C. and Dixon, R. (2016), "Not what it said on the tin? Reflections on three decades of UK public management reform", Financial Accountability \& Management, Vol. 32 No. 4, pp. 409-428.

Hood, C. and Jackson, M.W. (1991), Administrative argument, Wiley Online Library.

Hood, C. and Peters, B.G. (2004), "The middle aging of new public management: Into the age of paradox?", Journal of Public Administration Research and Theory, Vol. 14 No. 3, pp. 267-282.

Humphrey, C. and Scapens, R.W. (1996), "Methodological themes: Theories and case studies of organizational accounting practices: limitation or liberation?", Accounting, Auditing \& Accountability Journal, Vol. 9 No. 4, pp. 86-106.

Hyndman, N. and Lapsley, I. (2016), "New Public Management: The story continues", Financial Accountability \& Management, Vol. 32 No. 4, pp. 385-408. 
Jack, G., Zhu, Y., Barney, J., Brannen, M.Y., Prichard, C., Singh, K. and Whetten, D.A. (2013), “Refining, reinforcing and reimagining universal and indigenous theory development in international management.", Journal of Management Inquiry, Vol. 22 No. 2, pp. 148-164.

Jacobs, K. (2012), "Making sense of social practice: Theoretical pluralism in public sector accounting research", Financial Accountability \& Management, Vol. 28 No. 1, pp. 1-25.

Jacobs, K. (2013), "Making sense of social practice: Theoretical pluralism in public sector accounting research: a reply", Financial Accountability \& Management, Vol. 29 No. 1, pp. 111-115.

Jacobs, K. (2016), "Theorising interdisciplinary public sector accounting research", Financial Accountability \& Management, Vol. 32 No. 4, pp. 469-488.

Jacobs, K. and Cuganesan, S. (2014), "Interdisciplinary accounting research in the Public Sector", Accounting, Auditing \& Accountability Journal, Vol. 27 No. 8, pp. 1250-1256.

Jeacle, I. and Carter, C. (2014), "Creative spaces in interdisciplinary accounting research", Accounting, Auditing \& Accountability Journal, Vol. 27 No. 8, pp. 1233-1240.

Justesen, L. and Mouritsen, J. (2011), "Effects of actor-network theory in accounting research", Accounting, Auditing \& Accountability Journal, Vol. 24 No. 2, pp. 161-193.

Keating, P.J. (1995), "A framework for classifying and evaluating the theoretical contributions of case research in management accounting", Journal of Management Accounting Research, Vol. 7, pp. 66-86.

Kurunmäki, L. (2004), "A hybrid profession. The acquisition of management accounting expertise by medical professionals", Accounting, Organizations and Society, Vol. 29 3-4, pp. 327-347.

Lapsley, I. (1999), "Accounting and the new public management: Instruments of substantive efficiency or a rationalising modernity?", Financial Accountability \& Management, Vol. 15 3-4, pp. 201-207.

Lapsley, I. (2008), "The NPM agenda: Back to the future", Financial Accountability \& Management, Vol. 24 No. 1, pp. 77-96.

Llewelyn, S. (2003), "What counts as "theory" in qualitative management and accounting research? Introducing five levels of theorizing", Accounting, Auditing \& Accountability Journal, Vol. 16 No. 4, pp. 662-708.

Lüder, K. and Jones, R. (2003), Reforming Governmental Accounting and Budgeting in Europe, Fachverlag Moderne Wirtschaft, Frankfurt am Main.

Lukka, K. (2005), "Approaches to case research in management accounting: The nature of empirical intervention and theory linkage", Accounting in Scandinavia-The Northern Lights, Liber \& Copenhagen Business School Press, Kristianstad, SW, pp. 375-399.

Lukka, K. (2010), "The roles and effects of paradigms in accounting research", Management Accounting Research, Vol. 21 No. 2, pp. 110-115.

Lukka, K. and Vinnari, E. (2014), "Domain theory and method theory in management accounting research", Accounting, Auditing \& Accountability Journal, Vol. 27 No. 8, pp. 1308-1338.

Lukka, K. and Vinnari, E. (2017), "Combining actor-network theory with interventionist research. Present state and future potential", Accounting, Auditing \& Accountability Journal, Vol. 30 No. 3, pp. 720-753. 
Malmi, T. (2010), "Reflections on paradigms in action in accounting research", Management Accounting Research, Vol. 21 No. 2, pp. 121-123.

March, J.G. and Olsen, J.P. (1989), Rediscovering institutions: The organizational basis of politics, Free Press, New York, NY.

Massaro, M., Dumay, J. and Guthrie, J. (2016), “On the shoulders of giants. Undertaking a structured literature review in accounting", Accounting, Auditing \& Accountability Journal, Vol. 29 No. 5, pp. 767-801.

Mauro, S.G., Cinquini, L. and Grossi, G. (2016), "Insights into performance-based budgeting in the public sector. A literature review and a research agenda", Public Management Review, Vol. 19 No. 7, pp. 911-931.

McKinley, W., Mone, M.A. and Moon, G. (1999), "Determinants and development of schools in organization theory", Academy of Management Review, Vol. 24 No. 4, pp. 634-648.

Meredith, J.R. and Pilkington, A. (2018), "Assessing the exchange of knowledge between operations management and other fields. Some challenges and opportunities", Journal of Operations Management, Vol. 60, pp. 47-53.

Meyer, J.W. and Rowan, B. (1977), "Institutionalized organizations: Formal structure as myth and ceremony", American Journal of Sociology, pp. 340-363.

Meyer, M., Waldkirch, R.W., Duscher, I. and Just, A. (2018), "Drivers of citations: An analysis of publications in "top" accounting journals", Critical Perspectives on Accounting, Vol. 51, pp. 24-46.

Miller, P. and Rose, N. (1990), "Governing economic life”, Economy and Society, Vol. 19 No. 1, pp. 131.

Modell, S. (2013), "Making sense of social practice: theoretical pluralism in public sector accounting research: A comment", Financial Accountability \& Management, Vol. 29 No. 1, pp. 99-110.

Modell, S. (2015a), "Making institutional accounting research critical. Dead end or new beginning?", Accounting, Auditing \& Accountability Journal, Vol. 28 No. 5, pp. 773-808.

Modell, S. (2015b), "Theoretical triangulation and pluralism in accounting research. A critical realist critique", Accounting, Auditing \& Accountability Journal, Vol. 28 No. 7, pp. 1138-1150.

Modell, S. (2017a), "Critical realist accounting research: In search of its emancipatory potential", Critical Perspectives on Accounting, Vol. 42, pp. 20-35.

Modell, S., Vinnari, E. and Lukka, K. (2017b), "On the virtues and vices of combining theories. The case of institutional and actor-network theories in accounting research", Accounting, Organizations and Society, Vol. 60 No. 7, pp. 62-78.

Moore, M.H. (1995), Creating public value: Strategic management in government, Harvard university press.

Moore, M.H. (2014), "Public Value Accounting. Establishing the philosophical basis", Public Administration Review, Vol. 74 No. 4, pp. 465-477.

Newman, J. (2001), Modernising governance: New Labour, policy, and society, Sage, London, Thousand Oaks. 
Ni, C., Sugimoto, C.R. and Robbin, A. (2017), "Examining the evolution of the field of Public Administration through a bibliometric analysis of Public Administration Review", Public Administration Review, Vol. 77 No. 4, pp. 496-509.

Niskanen, W.A. (1971), Bureaucracy and representative government, Routledge, New York.

O'Dwyer, B. and Unerman, J. (2014), "Realizing the potential of interdisciplinarity in accounting research", Accounting, Auditing \& Accountability Journal, Vol. 27 No. 8, pp. 1227-1232.

Okhuysen, G. and Bonardi, J.-P. (2011), "The challenges of building theory by combining lenses", Academy of Management Review, Vol. 36 No. 1, pp. 6-11.

Oliver, C. (1991), "Strategic responses to institutional processes", Academy of Management Review, Vol. 16 No. 1, pp. 145-179.

Olson, O., Guthrie, J. and Humphrey, C. (1998), Global warning: Debating international developments in new public financial management, Cappelen Akademisk Folag.

Osborne, D. and Gaebler, T. (1992), Reinventing government: How the entrepreneurial spirit is transforming government, Addison Welsey, Reading MA.

Osborne, S.P. (2006), "The New Public Governance?", Public Management Review, Vol. 8 No. 3, pp. 377-387.

Parker, L.D. (2014), "Qualitative perspectives: Through a methodological lens", Qualitative Research in Accounting \& Management, Vol. 11 No. 1, pp. 13-28.

Parker, L.D. and Guthrie, J. (2014), "Addressing directions in interdisciplinary accounting research", Accounting, Auditing \& Accountability Journal, Vol. 27 No. 8, pp. 1218-1226.

Parker, L.D., Jacobs, K. and Schmitz, J. (2019), "New public management and the rise of public sector performance audit", Accounting, Auditing \& Accountability Journal, Vol. 32 No. 1, pp. 280-306.

Parker, L.D. and Northcott, D. (2016), "Qualitative generalising in accounting research. Concepts and strategies", Accounting, Auditing \& Accountability Journal, Vol. 29 No. 6, pp. 1100-1131.

Perry, J.L. and Wise, L.R. (1990), "The motivational bases of public service", Public Administration Review, Vol. 50 No. 3, p. 367.

Pilkington, A. (2018), "Bibexcel - Quick start guide to bibliometrics and citation analysis", in Daim, T. and Pilkington, A. (Eds.), Innovation discovery: Network analysis of research and invention activity for technology management, World Scientific Publishing, London, pp. 585-600.

Pilkington, A. and Meredith, J.R. (2009), "The evolution of the intellectual structure of operations management-1980-2006: A citation/co-citation analysis", Journal of Operations Management, Vol. 27 No. 3, pp. 185-202.

Pollitt, C. (1990), Managerialism and the public services: The Anglo-American experience, Blackwell, Oxford.

Pollitt, C. (2016), "Managerialism redux?", Financial Accountability \& Management, Vol. 32 No. 4, pp. 429-447.

Pollitt, C. and Bouckaert, G. (2000), Public management reform: A comparative analysis, Oxford University Press, Oxford.

Pollitt, C. and Bouckaert, G. (2004), Public management reform: A comparative analysis, 2nd ed., Oxford University Press, Oxford, New York. 
Pollitt, C. and Bouckaert, G. (2011), Public management reform: A comparative analysis: New public management, governance, and the Neo-Weberian state, 3rd ed., Oxford University Press, Oxford, New York.

Power, M. (1997), The audit society: Rituals of verification, Oxford University Press, Oxford [England], New York.

Reiter, R. and Klenk, T. (2019), "The manifold meanings of 'post-New Public Management' - a systematic literature review", International Review of Administrative Sciences, Vol. 85 No. 1, pp. 11-27.

Rhodes, R.A.W. (1997), Understanding governance: Policy networks, governance, reflexivity and accountability, Open University Press.

Riccucci, N. (2010), Public Administration: Traditions of inquiry and philosophies of knowledge, Public management and change series, Georgetown University Press, Washington, D.C.

Richardson, A.J. (2018), "The discovery of cumulative knowledge", Accounting, Auditing \& Accountability Journal, Vol. 31 No. 2, pp. 563-585.

Rost, K., Teichert, T. and Pilkington, A. (2017), "Social network analytics for advanced bibliometrics. Referring to actor roles of management journals instead of journal rankings", Scientometrics, Vol. 53 No. 2, p. 195.

Shafique, M. (2013), "Thinking inside the box? Intellectual structure of the knowledge base of innovation research (1988-2008)", Strategic Management Journal, Vol. 34 No. 1, pp. 62-93.

Small, H. (2006), "Tracking and predicting growth areas in science", Scientometrics, Vol. 68 No. 3, pp. 595-610.

Steccolini, I. (2019), "Accounting and the post-new public management", Accounting, Auditing \& Accountability Journal, Vol. 32 No. 1, pp. 255-279.

Stoker, G. (2006), "Public value management a new narrative for networked governance?", American Review of Public Administration, Vol. 36 No. 1, pp. 41-57.

van Helden, J.G. (2005), "Researching public sector transformation: The role of management accounting", Financial Accountability \& Management, Vol. 21 No. 1, pp. 99-133.

van Helden, J.G. and Northcott, D. (2010), "Examining the practical relevance of public sector management accounting research", Financial Accountability \& Management, Vol. 26 No. 2, pp. 213-240.

Vogel, R. (2014), "What happened to the public organization? A bibliometric analysis of public administration and organization studies", American Review of Public Administration, Vol. 44 No. 4, pp. 383-408.

von Krogh, G., Rossi-Lamastra, C. and Haefliger, S. (2012), "Phenomenon-based research in management and organisation science. When is it rigorous and does it matter?", Long Range Planning, Vol. 45 No. 4, pp. 277-298.

Whetten, D.A. (2009), "An examination of the interface between context and theory applied to the study of Chinese organizations", Management and Organization Review, Vol. 5 No. 1, pp. $29-55$.

White, H. and Griffith, B.C. (1981), "Author co-citation: A literature measure of intellectual structure”, Journal of the American Society for Information Science, Vol. 32, pp. 163-171. 
Wiesel, F., Modell, S. and Moll, J. (2011), "Customer orientation and management control in the public sector: A garbage can analysis", European Accounting Review, Vol. 20 No. 3, pp. 551-581.

Wright, B.E. (2011), "Public administration as an interdisciplinary field. Assessing its relationship with the fields of law, management, and political science", Public Administration Review, Vol. 71 No. 1, pp. 96-101.

Yin, R.K. (1994), Case study research: Design and methods, SAGE Publications.

Zupic, I. and Čater, T. (2015), "Bibliometric methods in management and organization", Organizational Research Methods, Vol. 18 No. 3, pp. 429-472. 
1 We refer to 'post-1990 PSA' as shorthand for PSA research undertaken after the conception of NPM; whilst we recognise an impact of NPM we don't infer that all post-1990 research has been framed within an NPM doctrinal view.

2 For our interests it is less important to evaluate whether the term NPM-paradigm adequately reflects the state of 'Scientific Revolution' as supposed by the sociology of scientific knowledge (Riccucci, 2010; Lukka, 2010). It is because the term is commonly used to address its distinctiveness in post-NPM and post-1990 PSA debates.

3 We decided not to add systematic reviews concerned with public budgeting (e.g. Mauro et al., 2016; Anessi-Pessina et al., 2016), particularly because of their incongruence in categorisation schemes and journal settings.

4 Methodology literature on the relevance of bibliometric analysis for mapping research fields substantiates our method decisions (Pilkington, 2018; Zupic and Čater, 2015; Small, 2006). In particular, Zupic and Čater (2015) summarised the strengths of the core bibliometric methods (citation/co-citation analysis, bibliographical coupling, co-author/co-word analysis) and their application. Basically, we aim to track NPM's emergence as a research field since 1991; we do not address and predict near term changes (Small, 2006) as our research is not trying to synthesise emerging NPM themes and their relationships. This might best be attempted with co-word analysis such as that referring to E-Government of Alcaide-Muñoz et al. (2017). In addition, our approach is strong as we are less interested in the nature of social networks created by collaborating NPM researchers as could be plotted using co-author analysis, or author co-citation analysis (e.g. Acedo et al., 2006). The literature on bibliometrics also reveals why science mapping is distinct to other approaches for synthesising prior research, e.g. structured literature reviews (referring accounting see Massaro et al., 2016; referring NPM see Reiter and Klenk (2019); referring E-Government see Alcaide-Muñoz and Rodríguez Bolívar, 2015). There are some previous examples of applying bibliometric analysis in NPM/PA research (Vogel, 2014; Ni et al., 2017) and our research is close to that published by Curry and van de Walle (2018) and Chandra and Walker (2018), which both address the relevance of the NPM template itself. Our role for bibliometrics is to deepen our understanding of NPM's knowledge base and its intellectual structure and as such citation/cocitation analysis is ideal (White and Griffith, 1981; Small, 2006). Citation analysis delivers a sense of whether insights from an NPM article remain useful to current research, indicating the scope and depth of NPM's knowledge base (Curry and van de Walle, 2018), whereas co-citation analysis visualises the intellectual structure as well as how knowledge nodes (publications) are connected, constitute a (new) research field, and also the interaction of such fields (Meredith and Pilkington, 2018; Chandra and Walker, 2018).

5 PMR is a new player in the field, with the first volume introduced in 2001. The peak of literature published in 2008 may be triggered by three special issues, dedicated to theoretical or practical concerns challenging the state of (N)PM research: collaborative networks, complexity theory, and public service innovation.

6 The figures show the most-highly co-cited references, using a co-citation rate that gave the most visually understandable diagram with about roughly the same number of nodes. Figure 4 shows only those co-cited items with links greater than 57, Figure 5 greater than 24, and Figure 6 greater than 45 . The node size is proportional to the number of citations and the thicker lines have stronger co-citation linkage. 
7 In order to generate this diagram (Figure 6) we show items with co-citation links greater than 9, but with items co-cited more than 60 times removed, hence leaving the supporting topics one layer beneath the Hood (1991) dominated core cluster. We used the same for Figures 8 (showing nodes co-citing greater than 10 times but removing those linked greater than 64 times) and 9 (showing greater than 11 , removing greater than 70 ).

8 Iterating empirical evidence with theoretical arguments is common to make inductive efforts reflexive. Our interpretive repertoire used for creating the 'inquiry-heritage' matrix is inspired by considering the role of epistemological sources for disciplinary development (Abbott, 2001). The matrix also applies some prescriptive, methodological reasoning about styles of theory building in management and accounting research, e.g. Okhuysen and Bonardi (2011), Parker and Northcott (2016). Hence, activating typological theorising (Cornelissen, 2017) enables us to cluster the observed patterns of inquiry into distinct, more theoretically grounded dimensions that reflect on the problematisation of disciplinary incoherence.

9 The 'inquiry-heritage' matrix is a preliminary, nascent step towards a theoretical typology as it refines our view on the nature of NPM's 'schooling'. Given the ideal (Cornelissen, 2017), elaborating distinct patterns of inquiry emphasises the diagnostic function of the matrix which is pre-conditional for groundwork on a full-blown typological theory. Synthesising them is a valuable outcome, because their distinctiveness serves as a means to scrutinise the desired typology. That's why we outline five types substantiated by our empirical material as intellectual sources supporting such thinking about post-1990 PSA research (or its follow ups). Yet, realising the ideal with a finergrained understanding of each cell is the signpost for future research. 
37307349_File000001_907197335.docx

Accounting, Auditing \& Accountability Journal

Paper: "Intellectual heritages of post-1990 public sector accounting research: An exploration"

Manuscript ID AAAJ-08-2018-3644.R3

List of figures (1-9) 


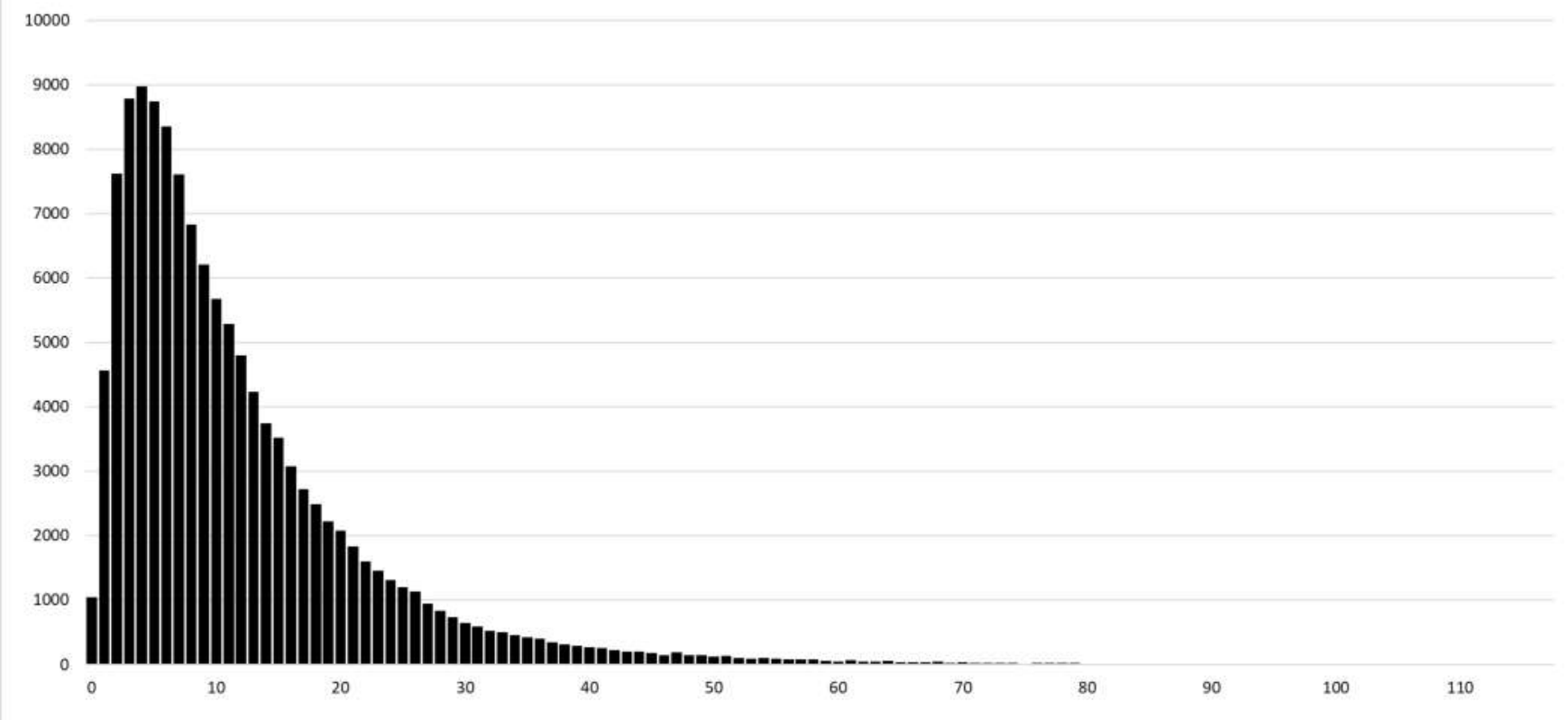

Figure 1: Disciplinary coherence 
Page 37 of 52

Accounting, Auditing \& Accountability Journal

37307349_File000001_907197335.docx

1
2
3
4
5
6
7
8
9

2

3

7

8

10

11

12

13

14

15

16

17

18

19

20

21

22

23

24

25

26

27

28

29

30

31

32

33

34

35

36

37

38

39

40

41

42

43

44

45

46

47

48

49

50

51

52

53

54

55

56

57

58

59

60

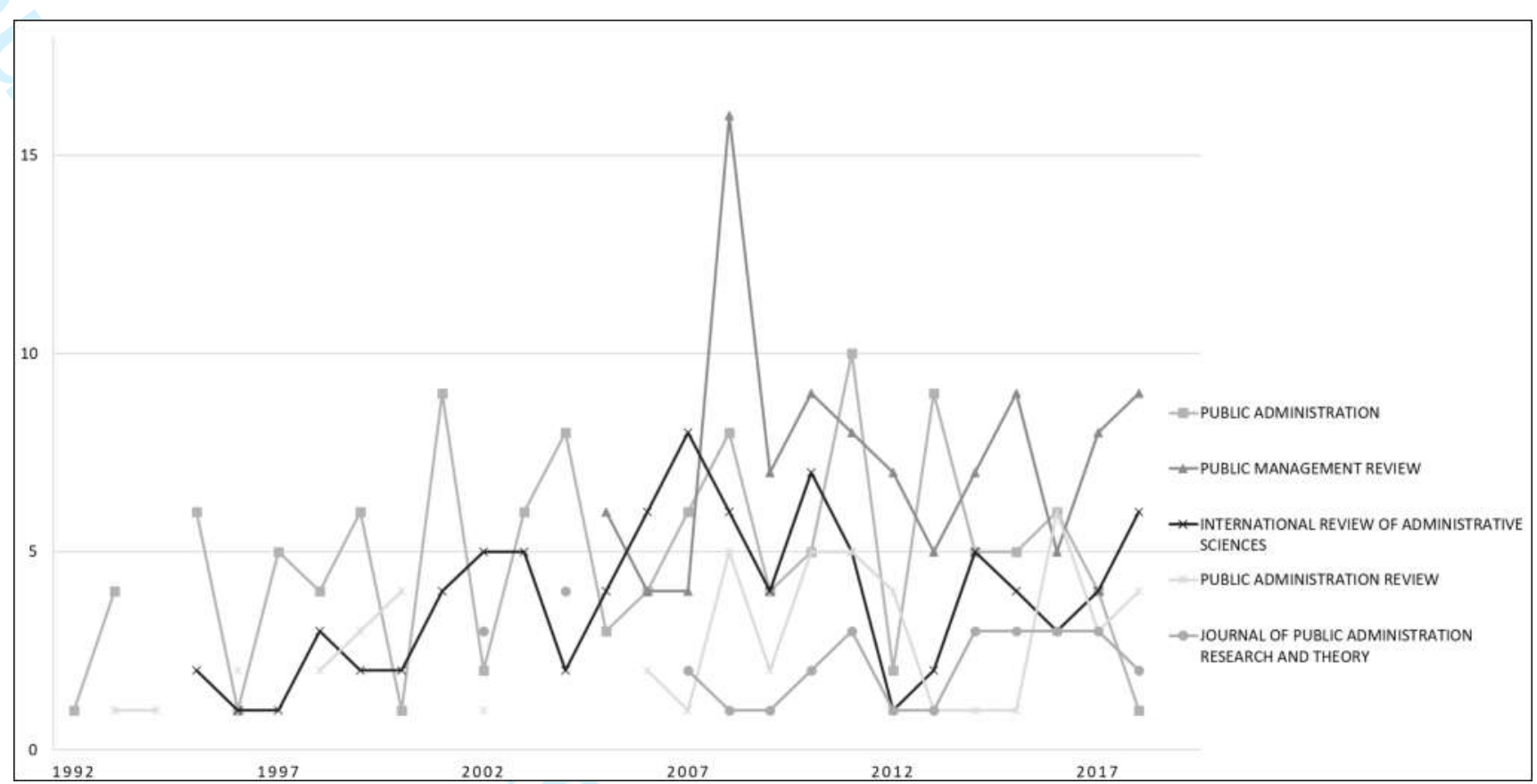

Figure 2: Public administration source journal articles collected by year (1991-2018)

3 
HOOD_C\$PUBL_ADMIN\$1991 HOOD_C\$ACCOUNT_ORG_SOC... OSBORNE_D\$REINVENTING_... POLLITT_C\$MANAGERIALIS... POLLITT_C\$PUBL_MANAG_R... FERLIE_E\$NEW_PUBLIC_MA... POWER_M\$AUDIT_SOC\$1997 YIN_RSCASE_STUDY_RES_D... POLLITT_C\$PUBL_MANAG_R... DIMAGGIO_P\$AM_SOCIOL_R... POLLITT_C\$PUBL_MANAG R... MEYER_J\$AM_J_SOCIOL\$19... RHODES_R\$UNDERSTANDING.. AUCOIN_P\$GOVERNANCE\$19.. DUNLEAVY_P\$PUBL_MONEY_... LIPSKY_M\$STREET_LEVEL_... DUNLEAVY_P\$J_PUBL_ADM_... MOORE_M\$SCREATING_PUBLI.. NISKANEN_WILLIAM_A\$BUR... BARZELAY_MSNEW_PUBLIC_...

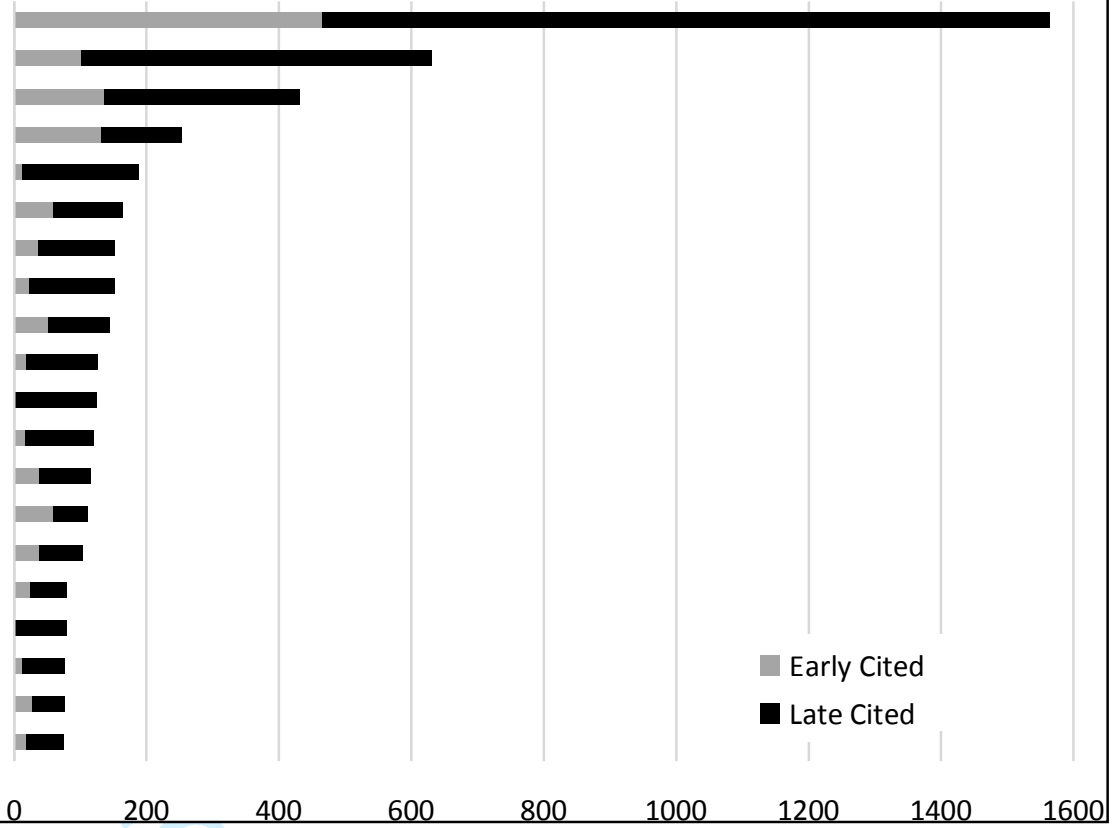

Figure 3: Change in citation frequency: Comparing the state of nascent (Early: 1991-2007) and intermediate research (Late: 2008-2018) 


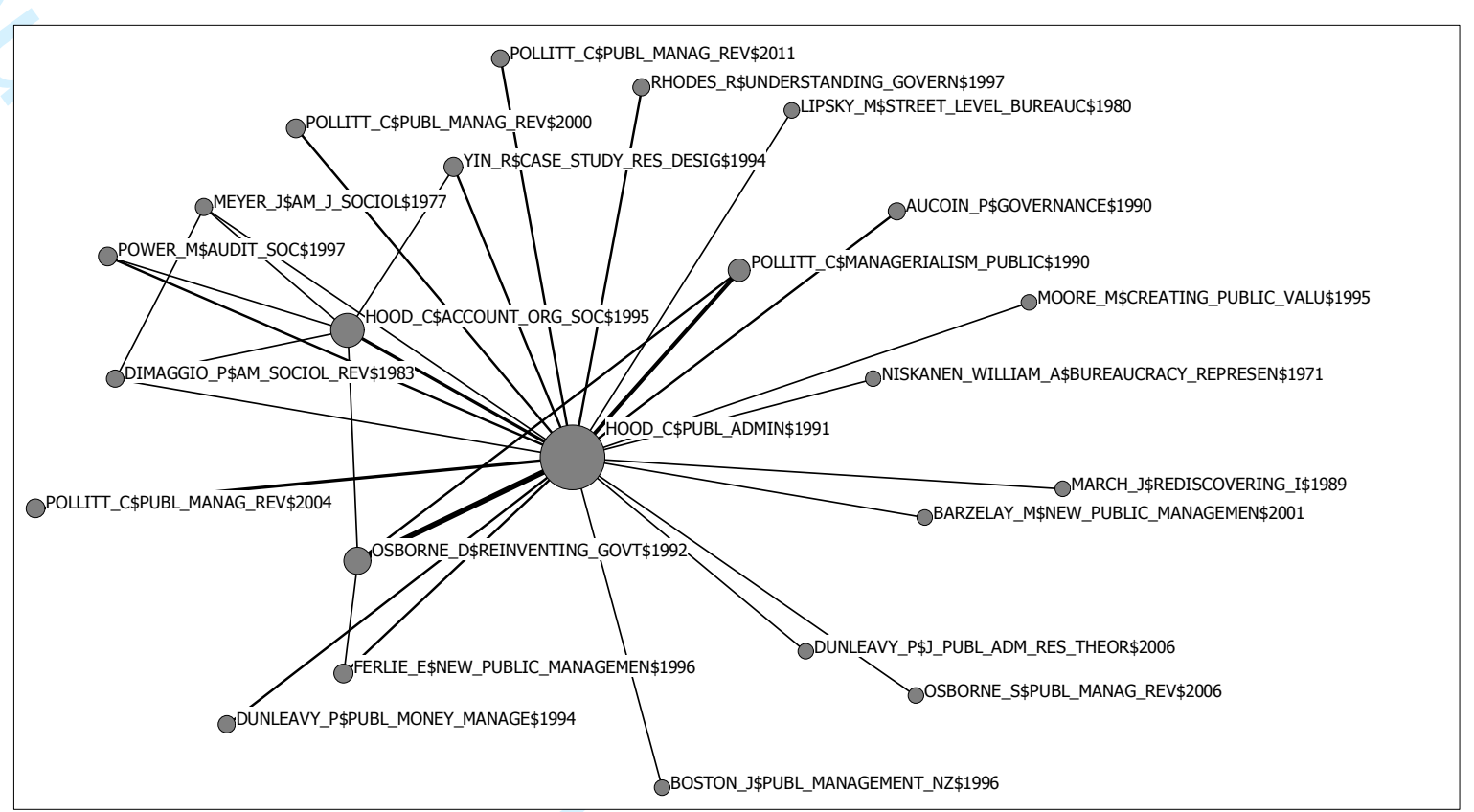

Figure 4: Co-citation map (All: 1991-2018) 


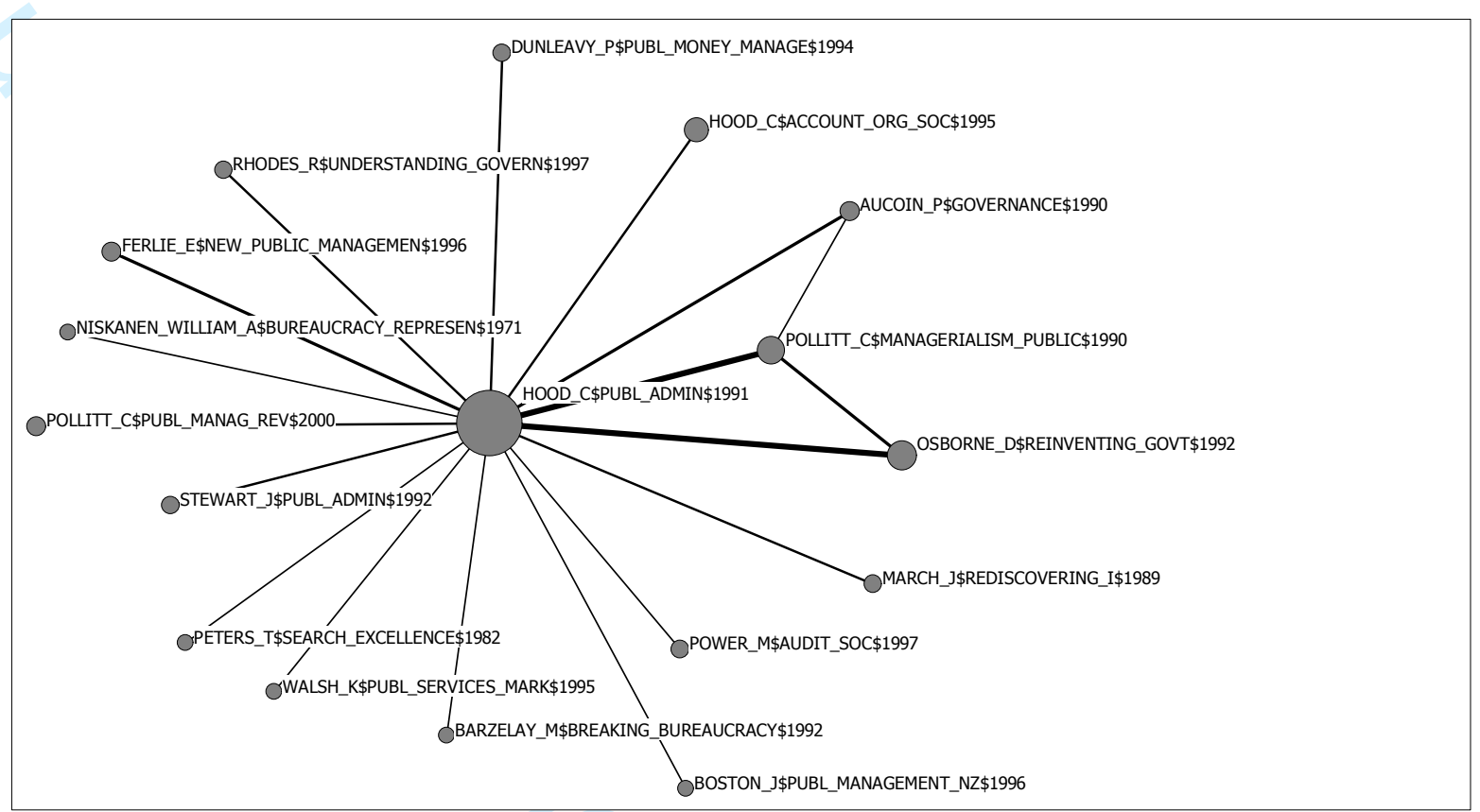

Figure 5: Co-citation map: Nascent research (Early: 1991-2007) 
37307349_File000001_907197335.docx

2

3

4

5

6

7

8

9

10

11

12

13

14

15

16

17

18

19

20

21

22

23

24

25

26

27

28

29

30

31

32

33

34

35

36

37

38

39

40

41

42

43

44

45

46

47

48

49

50

51

52

53

54

55

56

57

58

59

60

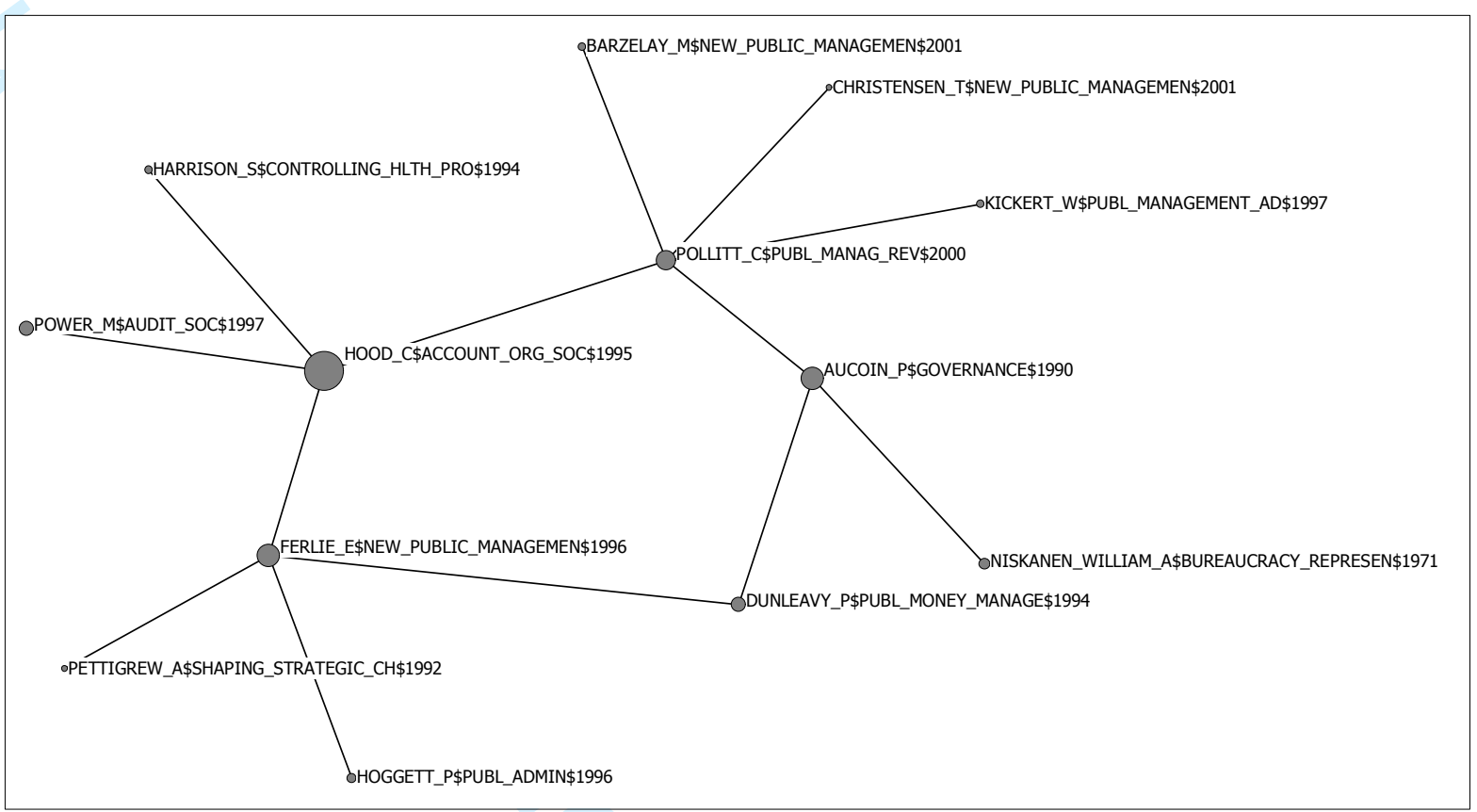

Figure 6: Co-citation map: Cutting off the top - nascent research (Early: 1991-2007) 


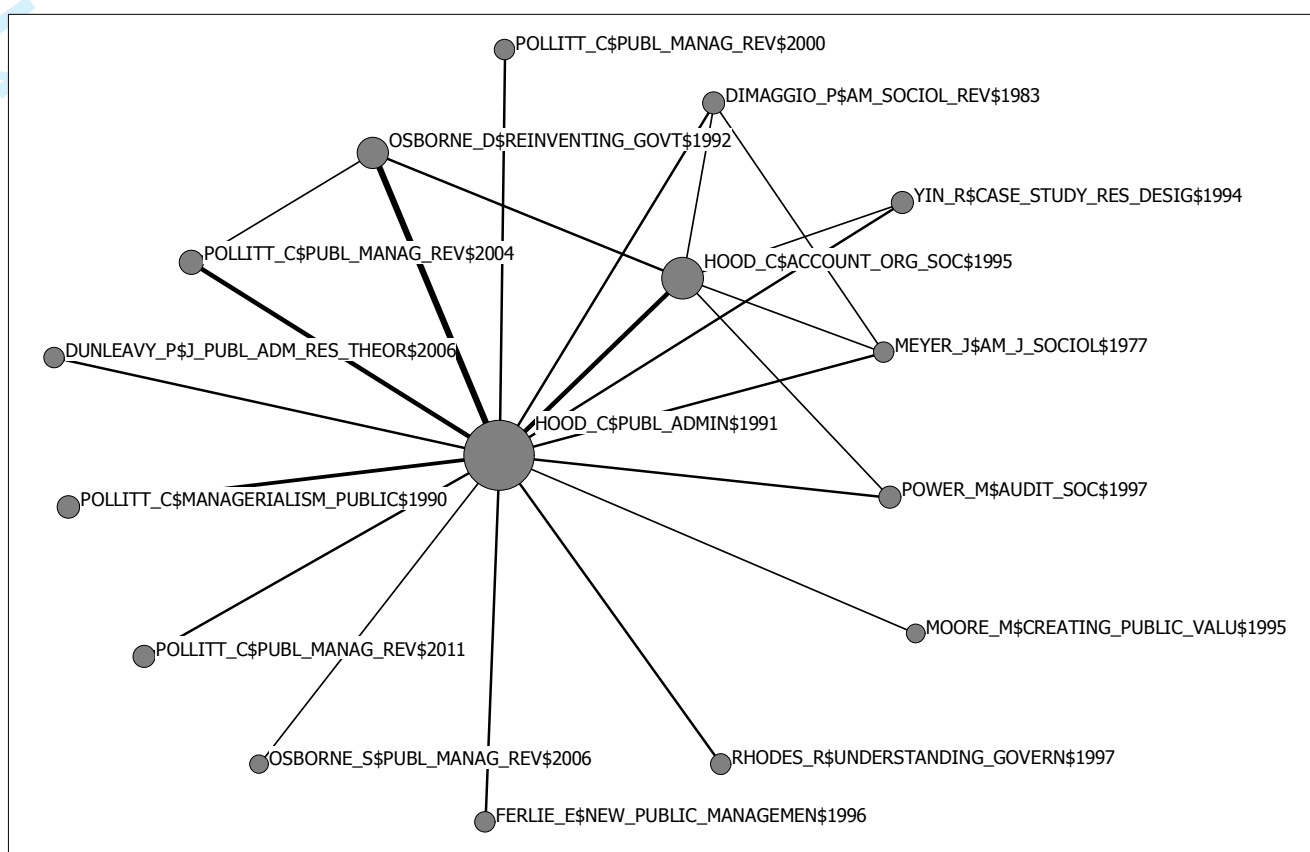

Figure 7: Co-citation map: Intermediate research (Late: 2008-2018) 

CHRISTENSEN_T\$TRANSCENDING_NEW_PUB $\$ 2007$ PPERRY_JPUBL_ADMIN_REV $\$ 1990$ HOOD_C\$J_PUBL_ADM_RES_THEOR $\$ 2004$ oPERRY_J\$_PUBL_ADM_RES_THEOR $\$ 1996$ LAPSLEY_I\$FINANC_ACCOUNT_MANAG $\$ 2008$ OLAPSLEY_I\$ABACUS $\$ 2009$ BROADBENT_J\$ACCOUNT_AUDITING\$2008

QAGRANOFF_R \$COLLABORATIVE_PUBLIC $\$ 2003$ OKOPPENJAN_J\$MANAGING_UNCERTAINTI\$2004

OKICKERT_WALTER_JMMMANAGING_COMPLEX_NET\$1997

RHODES_R\$UNDERSTANDING_GOVERN\$1997

ONEWMAN_J\$MODERNISING_GOVERNAN\$2001

OPIERRE_J\$GOVERNANCE_POLITICS $\$ 2000$

OSORENSEN_E\$THEORIES_DEMOCRATIC $\$ 2007$
OBOZEMAN_B\$PUBL_VALUES_PUBLIC $\$ 2007$ MOORE_M\$CREATING_PUBLIC_VALU $\$ 1995$ OO'FLYNN_J\$AUST_J_PUBL_ADMIN\$2 STOKER_G\$AM_REV_PUBLIC_ADM\$2 -KELLY_G\$CREATING_PUBLIC_VALU\$2002

OKURUNMAKI_L\$ACCOUNT_ORG_SOC\$2004 -MELIA_K\$MANAGE_ACCOUNTING $\$ 2003$

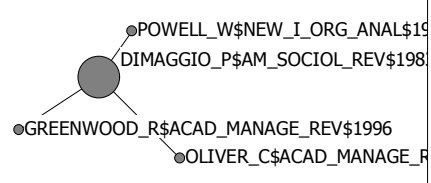

Figure 8: Co-citation map: Cutting off the top - intermediate research (Late: 2008-2018) 
37307349_File000008_907204421.docx

Accounting, Auditing \& Accountability Journal

Paper: "Intellectual heritages of post-1990 public sector accounting research: An exploration"

Manuscript ID AAAJ-08-2018-3644.R3

List of tables (1-5) 


\begin{tabular}{|c|c|c|c|c|}
\hline $\begin{array}{l}\text { PSA-related } \\
\text { reviews }\end{array}$ & $\begin{array}{l}\text { Years } \\
\text { covered }\end{array}$ & $\begin{array}{l}\text { Journals covered } \\
\text { / Total numbers }\end{array}$ & $\begin{array}{l}\text { Categorisation of theoretical } \\
\text { sourcing }\end{array}$ & Insight(s) considering theorising \\
\hline $\begin{array}{l}\text { Broadbent } \\
\text { and Guthrie } \\
(2008, \\
1992)\end{array}$ & $\begin{array}{l}1992- \\
2006\end{array}$ & $\begin{array}{l}\text { AAAJ, AF, AOS, } \\
\text { BAR, CPA, EAR, } \\
\text { FAM, MAR } \\
/ \mathrm{n}=452\end{array}$ & $\begin{array}{l}\text { - } \text { Case/ Field Study } \\
\text { - Content/ Historical Analysis } \\
\text { - Survey/ Questionnaire/ Other } \\
\text { Empirical } \\
\text { - Commentary/ Normative } \\
\text { - Theoretical/ Literature Review } \\
\text { - Theoretical/ Empirical }\end{array}$ & $\begin{array}{l}\text { Distinct research domains: } \\
\text { technical accounting, technical } \\
\text { contextual accounting, } \\
\text { contextually technical } \\
\text { accounting } \\
\text { - Omissions: empirically informed } \\
\text { theorising, theory and practice }\end{array}$ \\
\hline $\begin{array}{l}\text { van Helden } \\
(2005)\end{array}$ & $\begin{array}{l}1999- \\
2001\end{array}$ & $\begin{array}{l}\text { AAAJ, AOS, EAR, } \\
\text { FAM, MAR } \\
/ \mathrm{n}=55\end{array}$ & $\begin{array}{l}\text { Disciplinary-based } \\
\text { - Economics } \\
\text { - Organisation } \\
\text { - Neo-institutional } \\
\text { - Others } \\
\text { - No theory }\end{array}$ & $\begin{array}{l}\text { - Levels of theorising: general, } \\
\text { specific } \\
\text { - Dominant pattern: contextual, } \\
\text { higher-level, general theorising } \\
\text { - Absent pattern: contextualised, } \\
\text { specific, second-level theorising } \\
\text { (NPM-based) }\end{array}$ \\
\hline $\begin{array}{l}\text { Goddard } \\
\text { (2010) }\end{array}$ & $\begin{array}{l}2005- \\
2007\end{array}$ & $\begin{array}{l}\text { AAAJ, AOS, CPA, } \\
\text { EAR, FAM, MAR } \\
\text { (non-US) } \\
\text { JAPP, JPBAFM, } \\
\text { RGNPA (US) } \\
\text { / n=188 }\end{array}$ & $\begin{array}{l}\text { Paradigm-based } \\
\text { - Functionalist } \\
\text { - Interpretive } \\
\text { - Radical/alternative } \\
\text { - No theory (descriptive/ } \\
\text { normative) }\end{array}$ & $\begin{array}{l}\text { - Intermediate state: increasing } \\
\text { level of theoretically informed } \\
\text { inquiries } \\
\text { - Paradigmatic grouping, } \\
\text { geographically distinct: } \\
\text { positivistic (U.S.-based) or } \\
\text { interpretive/ critical theorising } \\
\text { (non-U.S.-based) }\end{array}$ \\
\hline $\begin{array}{l}\text { Jacobs } \\
\text { (2012) }\end{array}$ & $\begin{array}{l}1992- \\
2008\end{array}$ & $\begin{array}{l}\text { AAAJ, AF, AOS, } \\
\text { BAR, CPA, EAR, } \\
\text { FAM, AAR, MAR } \\
/ \mathrm{n}=758\end{array}$ & $\begin{array}{l}\text { Disciplinary-based } \\
\text { - Neo-institutional } \\
\text { - Economic } \\
\text { - Organisational } \\
\text { - Actor-Network (ANT) } \\
\text { - Political } \\
\text { - Foucault, Habermas, } \\
\text { - Bourdieu, Giddens } \\
\text { - No theory }\end{array}$ & $\begin{array}{l}\text { - Mode of theorising: Blending or } \\
\text { borrowing } \\
\text { - Multi-paradigm, e.g. blending } \\
\text { more than one approach, } \\
\text { patterns of theorising, e.g. neo- } \\
\text { institutional, Foucault, ANT } \\
\text { - No indigenous accounting } \\
\text { theory }\end{array}$ \\
\hline
\end{tabular}

Table 1: Exploring systematic, bibliographic-based PSA reviews 


\begin{tabular}{|c|c|c|c|}
\hline Reference & $\begin{array}{l}\text { Bibliographic data } \\
\text { (no of papers and citations } \\
\text { identified for co-citation } \\
\text { analysis) }\end{array}$ & $\begin{array}{l}\text { Leading Journals from } \\
\text { PA }\end{array}$ & $\begin{array}{l}\text { Qualifiers: } \\
\text { SSCI (WOB)-based ranking by Impact } \\
\text { Factor (2017): No of citations / Journal } \\
\text { Impact Factor / } 5 \text { Year Impact factor }\end{array}$ \\
\hline \multirow{5}{*}{$\begin{array}{l}\text { NPM } \\
\text { (with papers } \\
\text { citing Hood } \\
1991 \text { or } \\
\text { Hood 1995) }\end{array}$} & \multirow{5}{*}{$\begin{array}{l}\text { - Number of source } \\
\text { papers: } 2,016 \\
\text { - Number of citations to } \\
\text { number of publications: } \\
128,496 / 2,016=63.74 \\
\text { - Periods used for } \\
\text { analysis: } \\
\text { Early: } 1991-2007 \\
\text { Late: } 2008-2018\end{array}$} & Publ Adm & $\begin{array}{l}\text { - SSCl-Ranking 9: } \\
\text { 3,447 / } 2.870 \text { / } 2.954\end{array}$ \\
\hline & & Pub Man Rev & $\begin{array}{l}\text { - SSCl-Ranking 6: } \\
\text { 2,191 / } 3.152 \text { / } 3.088\end{array}$ \\
\hline & & Int Rev Ad Sci & $\begin{array}{l}\text { - SSCl-Ranking 17: } \\
\text { 1,117 / } 1.988 \text { / } 2.289\end{array}$ \\
\hline & & Publ Admin Rev & $\begin{array}{l}\text { - SSCl-Ranking 1: } \\
\text { 7,651/ } 4.591 \text { / } 5.284\end{array}$ \\
\hline & & J Publ Adm Res Theor & $\begin{array}{l}\cdot \text { SSCI-Ranking 2: } \\
\text { 4,543 / } 3.907 \text { / } 5.536\end{array}$ \\
\hline
\end{tabular}

Table 2: Source data profile 


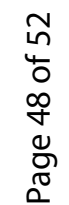

品 员

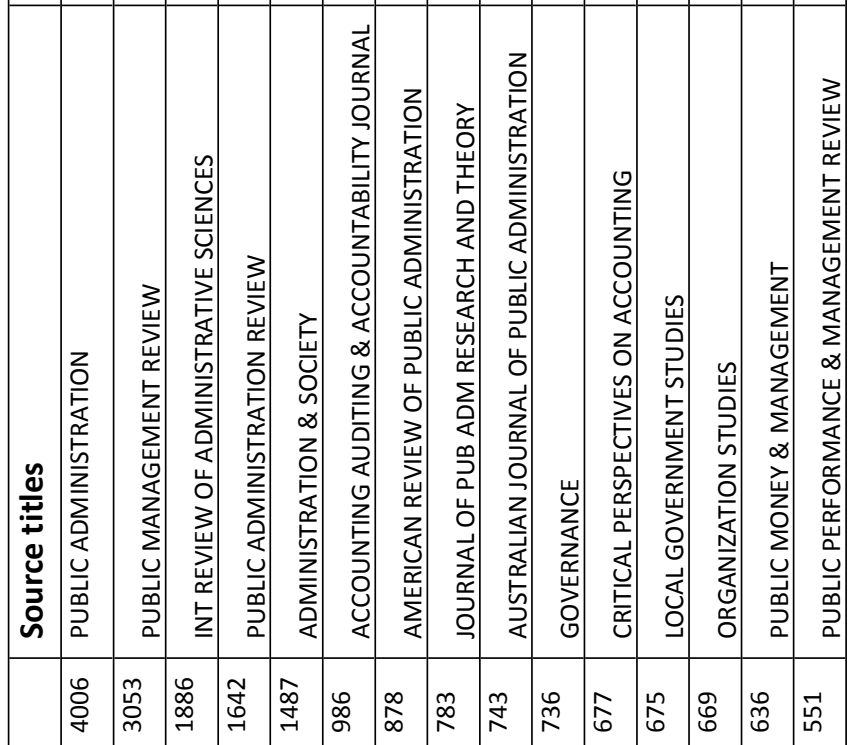

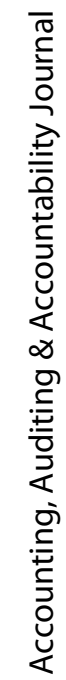
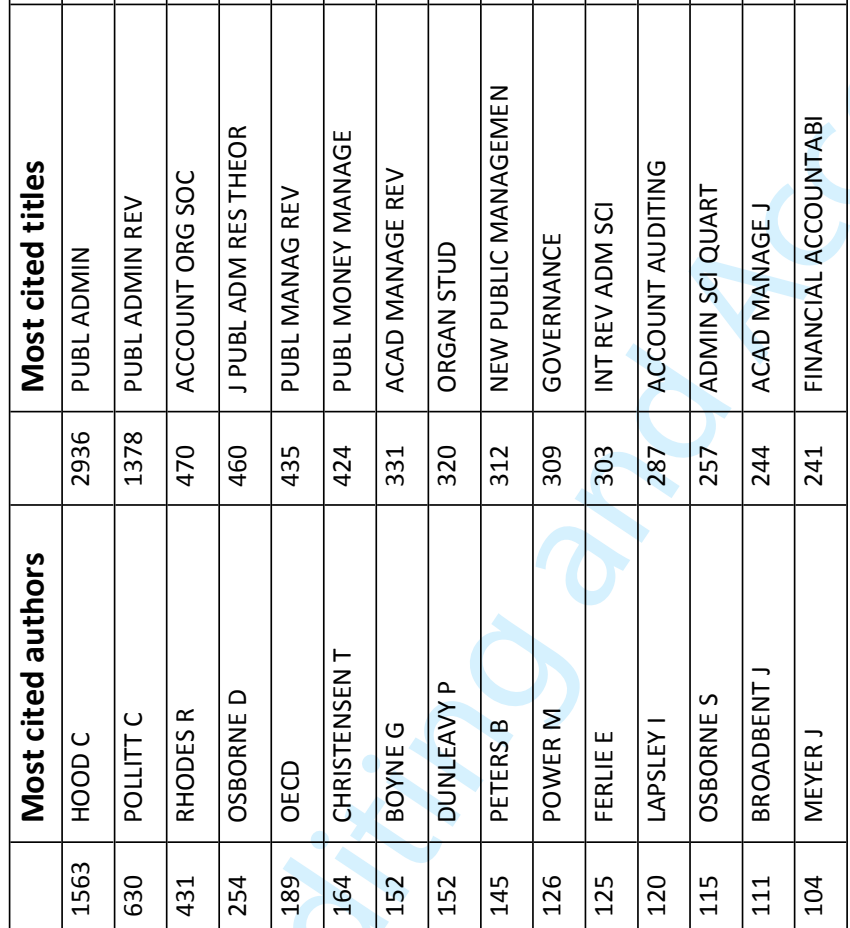

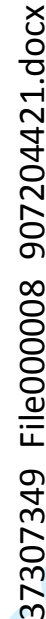

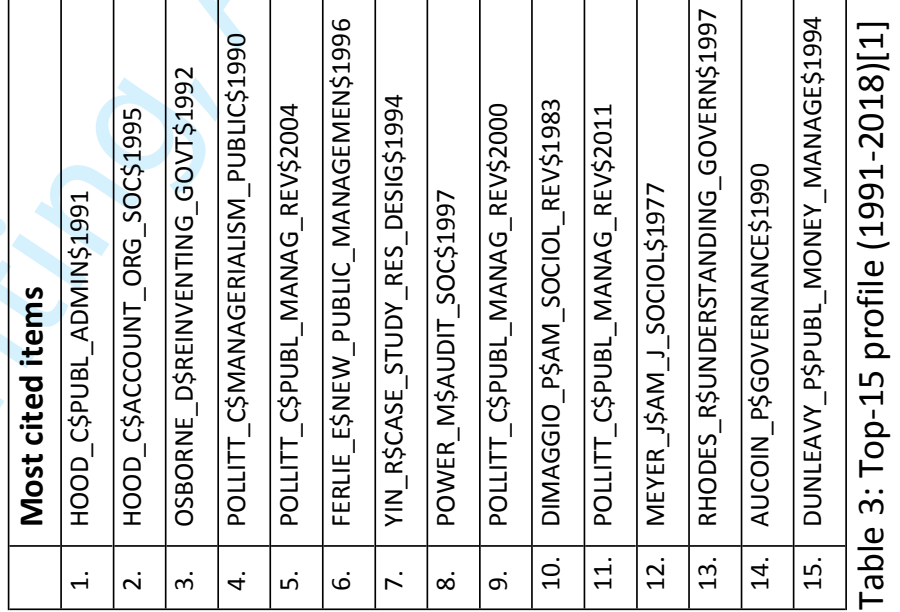


37307349_File000008_907204421.docx

\begin{tabular}{|l|l|l|l|l|}
\hline \multicolumn{2}{|l|}{ Early period (1991-2007) } & \multicolumn{2}{l|}{ Late period (2008-2018) } \\
\hline 465 & HOOD_C\$PUBL_ADMIN\$1991 & 1 & 1098 & HOOD_C\$PUBL_ADMIN\$1991 \\
\hline 137 & OSBORNE_D\$REINVENTING_GOVT\$1992 & 2 & 528 & HOOD_C\$ACCOUNT_ORG_SOC\$1995 \\
\hline 132 & POLLITT_C\$MANAGERIALISM_PUBLIC\$1990 & 3 & 294 & OSBORNE_D\$REINVENTING_GOVT\$1992 \\
\hline 102 & HOOD_C\$ACCOUNT_ORG_SOC\$1995 & 4 & 176 & POLLITT_C\$PUBL_MANAG_REV\$2004 \\
\hline 60 & FERLIE_E\$NEW_PUBLIC_MANAGEMEN\$1996 & 5 & 129 & YIN_R\$CASE_STUDY_RES_DESIG\$1994 \\
\hline 60 & AUCOIN_P\$GOVERNANCE\$1990 & 6 & 125 & POLLITT_C\$PUBL_MANAG_REV\$2011 (3.Ed.) \\
\hline 52 & POLLITT_C\$PUBL_MANAG_REV\$2000 & 7 & 122 & POLLITT_C\$MANAGERIALISM_PUBLIC\$1990 \\
\hline 39 & DUNLEAVY_P\$PUBL_MONEY_MANAGE\$1994 & 8 & 115 & POWER_M\$AUDIT_SOC\$1997 \\
\hline 38 & RHODES_R\$UNDERSTANDING_GOVERN\$1997 & 9 & 107 & DIMAGGIO_P\$AM_SOCIOL_REV\$1983 \\
\hline 37 & POWER_M\$AUDIT_SOC\$1997 (old: 22) & 10 & 104 & FERLIE_E\$NEW_PUBLIC_MANAGEMEN\$1996 \\
\hline 36 & STEWART_J\$PUBL_ADMIN\$1992 & 11 & 103 & MEYER_J\$AM_J_SOCIOL\$1977 \\
\hline 34 & MARCH_J\$REDISCOVERING_I\$1989 (old: 41) & 12 & 93 & POLLITT_C\$PUBL_MANAG_REV\$2000 \\
\hline 28 & WALSH_K\$PUBL_SERVICES_MARK\$1995 & 13 & 80 & DUNLEAVY_P\$_PUBL_ADM_RES_THEOR\$2006 \\
\hline 28 & NISKANEN_WILLIAM_A\$BUREAUCRACY_REPRESEN\$1971 & 14 & 77 & RHODES_R\$UNDERSTANDING_GOVERN\$1997 \\
\hline 27 & PETERS_T\$SEARCH_EXCELLENCE\$1982 & 15 & 65 & DUNLEAVY_P\$PUBL_MONEY_MANAGE\$1994 \\
\hline
\end{tabular}

Table 4: Most cited publications: Comparing Top-15 profile of the nascent and intermediate research 
- Theorising in applied science: How theoretical claims are extended by domain-specific reasoning? Defining the substantive topic of theorisation (domain theory)

1 The reference list of source titles identified by citation/co-citation analysis and exhibited in Tables and Graphs is available on request from the authors.

Epistemological heritage: Patterns of grounding PSA theorisation (method theory)

\begin{tabular}{|c|c|c|c|c|}
\hline \multicolumn{2}{|c|}{ domain-specific reasoning? } & $\begin{array}{l}\text { Discovery: What is? } \\
\text { - Tentative theory } \\
\text { generation }\end{array}$ & $\begin{array}{l}\text { Borrowing: What is new? } \\
\text { - Refining or reinforcing a } \\
\text { theory by explaining } \\
\text { variations }\end{array}$ & $\begin{array}{l}\text { Blending: What is different? } \\
\text { - Re-imagining: Conclusive theory } \\
\text { generation }\end{array}$ \\
\hline \multirow{3}{*}{$\begin{array}{l}\text { Research inquiry: } \\
\text { Defining the } \\
\text { substantive topic } \\
\text { of theorisation } \\
\text { (domain theory) }\end{array}$} & $\begin{array}{l}\text { Context-sensitive } \\
\text { topic } \\
\text { - NPM and its } \\
\text { doctrines, therein } \\
\text { accounting } \\
\text { packages }\end{array}$ & $\begin{array}{l}\text { (b) Ethnographic } \\
\text { - Context specific } \\
\text { concepts, valid only for } \\
\text { the particular local, } \\
\text { institutional setting }\end{array}$ & & $\begin{array}{l}\text { (d) Local strategy by building } \\
\text { blocks } \\
\text { - Shared knowledge about causal } \\
\text { mechanisms when considering } \\
\text { an historically dominated case or } \\
\text { problem }\end{array}$ \\
\hline & $\begin{array}{l}\text { Context-sensitive } \\
\text { factors / effects } \\
\text { - Contextualising } \\
\text { NPM / PSA }\end{array}$ & & $\begin{array}{l}\text { (a) Bounded midrange } \\
\text { - Endogenous concepts, } \\
\text { placed by their conceptual } \\
\text { or contextual boundaries }\end{array}$ & \\
\hline & $\begin{array}{l}\text { Context-specific } \\
\text { theory } \\
\text { - NPM / PSA as a } \\
\text { contextualised } \\
\text { practice }\end{array}$ & $\begin{array}{l}\text { (c) Domain-specific } \\
\text { - High quality indigenous } \\
\text { research }\end{array}$ & & $\begin{array}{l}\text { (e) Polymath discipline } \\
\text { - Field-level interdisciplinarity }\end{array}$ \\
\hline
\end{tabular}

Table 5: The 'Inquiry-heritage' matrix: A landscape for theorisation in NPM-based PSA research 